Illinois State University

ISU ReD: Research and eData

Theses and Dissertations

7-14-2014

\title{
Another Kind of Pink Tide? An Investigation into the Rapid Expansion of LGBT Rights in Latin America
}

Christopher Joseph Petkus

Illinois State University, cjpetku@ilstu.edu

Follow this and additional works at: https://ir.library.illinoisstate.edu/etd

Part of the International Relations Commons, and the Public Policy Commons

\section{Recommended Citation}

Petkus, Christopher Joseph, "Another Kind of Pink Tide? An Investigation into the Rapid Expansion of LGBT Rights in Latin America" (2014). Theses and Dissertations. 220.

https://ir.library.illinoisstate.edu/etd/220

This Thesis is brought to you for free and open access by ISU ReD: Research and eData. It has been accepted for inclusion in Theses and Dissertations by an authorized administrator of ISU ReD: Research and eData. For more information, please contact ISUReD@ilstu.edu. 


\title{
ANOTHER KIND OF PINK TIDE? AN INVESTIGATION INTO THE RAPID EXPANSION OF LGBT RIGHTS IN SOUTH AMERICA
}

\author{
Christopher J. Petkus
}

87 Pages

August 2014

Within the past two decades or so, the South American region has seen a remarkable rise in the enactment of LGBT (lesbian, gay, bisexual, and transgender) rights-affirming policies. This trend is particularly notable given the dearth of such progress in the rest of the developing world. As such, this study aims to contribute to the small but rapidly growing body of literature on the subject. In particular, I aim to determine which factors are most explanatory of when and why countries will enact LGBT rights policies and why a disparity exists across the region. The first systematic study of its kind, findings suggest that social movements, the language of a state's constitution, and religious trends are most influential in this regard. Noting the limitations of the research, I proceed to suggest possible future research directions. 


\section{ANOTHER KIND OF PINK TIDE? AN INVESTIGATION INTO THE RAPID EXPANSION OF LGBT RIGHTS \\ IN SOUTH AMERICA}

CHRISTOPHER J. PETKUS

A Thesis Submitted in Partial Fulfillment of the Requirements for the Degree of

MASTER OF SCIENCE

Department of Politics and Government

ILLINOIS STATE UNIVERSITY 
(C)2014 Christopher J. Petkus 
ANOTHER KIND OF PINK TIDE? AN INVESTIGATION INTO

THE RAPID EXPANSION OF LGBT RIGHTS

IN SOUTH AMERICA

CHRISTOPHER J. PETKUS

COMMITTEE MEMBERS:

Carlos A. Parodi, Chair

Carl Palmer

Lori Riverstone-Newell 


\section{ACKNOWLEDGMENTS}

I must express my sincerest gratitude to Drs. Parodi, Palmer, and Riverstone for their patience on this project and their granting my ability to see it through as a positive development for possible future research endeavors. I know this will, if nothing else, serve as a fine stepping stone for any additional graduate work, be it political science, law, or elsewhere. I was honored to be granted the ability to pursue such in-depth research on such an important subject taking place in such an enchanting region of the world. I must also thank my boyfriend for doing so much to allow me to maintain my mental and emotional well-being while pursuing the degree for which this thesis serves as a partial completion.

C.J.P. 


\section{CONTENTS}

Page

ACKNOWLEDGMENTS $\quad$ i

$\begin{array}{ll}\text { CONTENTS } & \text { ii }\end{array}$

TABLES $\quad$ iv

FIGURES $\quad$ V

\section{CHAPTER}

I. CLARIFICATION OF THE RESEARCH QUESTION 1

II. BROAD THEORETICAL BACKGROUND 3

Preface 3

Some Historical Context on the Expansion of Rights

Generally 5

The Globalization of Civil and Human Rights $\quad 7$

Defining LGBT Rights: Beyond a Single, Concrete Policy 11

On the Social-Legal Disparity in General 12

Legal vs. Real for LGBT People in the Developed World 14

The Environment as it Currently Stands for LGBT People In South America

III. PRELIMINARY CASE STUDIES 21

The Social Movement Process 21

Emergence and Identity Formation 21

Factionalization $\quad 25$

Identity Synthesis $\quad 29$

Argentina and the Spanish Precedent 31

Judicial Innovation in Brazil 36 
Developments for LGBT Rights in Other South American

Countries

Preliminary Conclusions

IV. CONCEPTUAL FRAMEWORK AND HYPOTHESES

Constitutional Language

Federalism

Social Movements

50

Institutional Factors

51

LGBT Rights Opposition

V. VARIABLE SELECTION FOR HYPOTHESIS TESTING

Establishing the Scope of Jurisdiction

Dependent Variable

Independent Variables

VI. ANALYSIS

Descriptive Statistics

VII. DISCUSSION

$\begin{array}{lll}\text { VIII. LIMITATIONS } & 76\end{array}$

IX. DIRECTIONS FOR FUTURE RESEARCH 78

$\begin{array}{ll}\text { REFERENCES } & 81\end{array}$

APPENDIX: Variable Measurement and Data Sources 86 


\section{TABLES}

Table Page

1. LGBT Rights-affirming Policies by Country and Year of Enactment 66

2. Descriptive Statistics for Independent Variables 67

3. Factors Influencing State Action on LGBT Rights 72 


\section{FIGURES}

Figure

Page

1. Cumulative Attempts at Passage of LGBT Rights Initiatives, 2000-2013 68 


\section{CHAPTER I}

\section{CLARIFICATION OF THE RESEARCH QUESTION}

Within the past decade or so, a conspicuous shift in social policy has swept across the South American region in which policies aimed at promoting lesbian, gay, bisexual, and transgender (LGBT) rights are rapidly approaching the norm. This is a notable trend in part because most of the rest of the developing world continues to prove an overwhelmingly hostile environment for LGBT persons while virtually all progress has occurred in Europe and North America. Furthermore, the South American region serves as the center of gravity for the Catholic Church, which remains unambiguously opposed to most policy that explicitly recognizes or provides protective status for LGBT persons. As such, this trend appears counterintuitive on its face, and suggests that a unique blend of factors must be at work in order for this kind of rapid advancement to occur.

The purpose of this project is first and foremost to discern which factors are most pertinent to the expansion of LGBT rights so as to glean lessons for future efforts. In addition, this should serve as a contribution to a still fledgling body of literature on LGBT rights in South America specifically - literature that shows little more than a speculative, journalistic account of the phenomenon. In an effort to explore these developments more in-depth, I intend to employ a more robust and systematic 
hypothesis-testing procedure in an effort to shed more light on why the policies in question have moved forward in the times and places that they have, thereby paving the way both for future efforts in other countries or for related efforts within the same countries. In an effort to determine these factors, we will have to assess those via the relevant literature - institutional, socioeconomic, social movements, socioeconomic, and international norms. In order better highlight how these factors have influenced changes in LGBT rights policy; we will examine the pertinent factors within each country in South America. This allows for an effective controlling of such baseline factors as religion, language, culture, and to a great extent, institutional frameworks. Before proceeding, we need to understand that the development of LGBT rights has not been uniform across the continent to date. As such, every effort possible should be made to determine the relevant control variables, followed by which of those variables are most pertinent to the question at hand. 


\section{CHAPTER II}

\section{BROAD THEORETICAL BACKGROUND}

\section{Preface}

By and large, the central focus of human rights over the past three or four centuries has shifted away from nations or other collectivities and increasingly toward the individual. In order to discern common lessons that may be applied to any one subset of rights; it is paramount that one examines the broader framework of human rights and its progression in different frames and environs. In this section, in an attempt to understand how LGBT rights can be expected to progress, we will discern some common mechanisms by which rights have been achieved and sustained more generally. This should be instructive when attempting to examine the expansion of such rights in any particular region, and is crucial when determining which factors to hold constant in such an analysis.

There is a variety of interconnecting factors - some of which are largely unique to Latin America, and some of which are unique to the formulation of LGBT rights on the whole - which coalesce to form a very unique situation on the ground when it comes to the establishment of LGBT rights within this particular region. Javier Corrales (2014) speculates that the usual correlation between national income and respect for LGBT and 
other civil rights has defied expectations unlike any other country or region to date. Rather, a better predictor in this case is the strength of ties between social movements and political parties with substantial power in a legislature, with Corrales pointing to the willingness of LGBT rights groups to work with the then governing center-right party to craft what became a successful hate crimes law. In addition, Corrales points to the separation of church and state as a vital component in success for LGBT initiatives, with Catholic and sometimes Protestant organizations serving as the chief roadblocks to reform. Elizabeth J. Friedman (2014) emphasizes the importance of rapidly developing international norms concerning human rights, and the role that such a phenomenon plays in a region which was plagued by decades of military dictatorships and saw a human rights discourse develop in response to it. For one, she notes that "shrewd street activists" emerged to form increasingly sophisticated lobbying apparatuses which became highly influential in left-wing politics by the 1990s (2014). In addition, activists from Spain have provided advice and material resources to activists across Latin America, including Mexico and particularly Argentina.

Within the judicial realm, a number of concurrent developments have taken place that have worked to the benefit of several LGBT rights causes. Interestingly, Omar Encarnación (2014) observes that the 1967 U.S. Supreme Court decision Loving v. Virginia has set the stage for a number of court decisions in countries such as Brazil, Mexico and, Colombia. Furthermore, because marriage in most of Latin America is a strictly civil institution in contrast with the religious understanding of marriage in the U.S., there is less legal precedent by which judges might justify rulings detrimental to same-sex unions. Finally, Daniel de la Cruz (2013) has written what is quite possibly the widest-reaching analysis of 
LGBT rights in Latin America to date, and the hypotheses that his study formulates will largely albeit not entirely coincide with those developed for this study. In essence, the effects of language in a national constitution, the limitations of the courts, the influence of and barriers before LGBT rights groups, and the specific nature of the religious opponents to reform all play key roles in the development of LGBT rights across the region.

Following these initial observations, I shall lay out some brief context for the development of civil rights in general, followed by further exploration of how these norms tend to play out in the modern era. It will then be prudent to establish the full scope of what the study intends to cover with respect to LGBT rights, and what specifically that concept entails.

Some Historical Context on the Expansion of Rights Generally

The development of civil rights for previously excluded groups has developed from a centuries-long process of development in the conception of human rights. People have moved from being seen as subjects of a monarch to citizens of a sovereign state endowed with natural rights, though not everyone (women, minorities, etc.) was immediately entitled to these rights when first codified in such documents as The Two Treatises of Government or the United States Constitution. Various minorities and longstigmatized groups have struggled and continue to struggle for full inclusion, either by disenfranchisement within the political process or by failures on the part of the state to protect the rights of such groups from what Thomas Jefferson often dubbed the tyranny of the majority. The women's suffrage and African American civil rights movements in the U.S. are among the most vivid examples of this. Rights, by and large, are effectively 
meaningless absent consistent enforcement on the part of the state. Thus, it is necessary to assess the behaviors and incentives driving states in order to discern the likelihood that certain rights will be respected.

With respect to state actors, Michael Haas (2014) outlines a thesis in which: (1) Legal norms establish the minimally accepted boundaries of rights; (2) State institutions persist in monitoring and enforcing these rights; and (3) External pressure groups keep the state in check both in terms of preventing abuses and facilitating protection. In effect, this mechanism consists of a set of checks and balances wherein pressure groups both internal and external press for greater protections of human rights, often by way of specialized single-issue interest groups. Once the state establishes these protections, often through an ombudsman office or other specialized agencies, pressure to maintain a new status quo is applied to the state so as to ensure that these protections do not flag. A larger-picture historical process leading up to this norm is outlined by Christian ReusSmit (2011). In essence, his thesis postulates that tipping points or punctuated equilibria can be seen throughout history - the Westphalian settlement of the late $17^{\text {th }}$ century, the wave of independence across Latin America in the early $19^{\text {th }}$ century, and the post-1945 wave of independence across former European colonies in the developing world cited as prominent examples. This series of events is ultimately dubbed by Reus-Smit as the "generative paradox of rights and sovereign states" (p. 237). The paradox from this stems from the fact that although historical struggles for individual rights have historically rallied around nationalism and demands for state sovereignty from empire, the sovereign states that result from these pushes are themselves often failed guarantors of the rights 
that were sought. This has been demonstrated at least in part by the eruption of civil wars in much of Africa and Asia after the British and French Empires relinquished much of their power in those regions following the Second World War. One interpretation of this which would fit into a broader examination of how the conception of human rights has developed over the centuries is that the locus of agency has shifted from national sovereignty and toward the plight of individuals within these sovereign territories.

Thus, when determining what propels the development of LGBT rights in South America as well as the disparities seen in the process thereof, among the most crucial factors to analyze is the incentive structure of the states in question. Furthermore, genuine protection of any kind of rights cannot be accomplished through a one-off action, but rather through a sustained commitment and a shift in human rights norms. Additionally, it is worth noting that the international community has grown exponentially more important in introducing as well as reinforcing human rights in much of the developing world. Uganda, for instance, has received a great deal of pushback in response to its controversial 2014 law punishing sodomy by imposing life imprisonment (Escobedo, 2014). Such a shift in the enforcement of global norms is a relatively recent phenomenon that should be explored briefly in the context of this project.

\section{The Globalization of Civil and Human Rights}

The boomerang effect, in the context of international human rights, describes a situation in which a domestic human rights group sends out a call - a boomerang - to the international community for aid to counter any repressive tactics employed by the state. 
In the event that an international human rights organization (HRO) responds with material resources and/or personnel to aid their domestic counterparts in a relatively repressive country, the state can be targeted "from below" (Keck \& Sikkink, 1998; Brysk, 2003; Sikkink, 2008; Murdie \& Davis, 2012; Holzhacker, 2013). The overarching thesis is that the boomerang phenomenon has in large part proven responsible for the more recent gains in human rights practices in most of the developing world. Following this, particularly after sections of the local population has been educated on a given matter and then mobilized; they often seek aid from more influential states so as to lead to pressure from above. Building on this model, Risse and Sikkink (1999) outline a "spiral" model in which states move from repression to fully internalized respect for human rights norms. This typically begins in the form tactical concessions in response to shaming and other pressures from the international community. As long as such pressure is maintained, the state in question will continue to concede repressive behaviors in lieu of attempting to evade them, leading to habituation and eventual internalization. The last stage generally occurs when heads of state and government as well as legislators and public administrators integrate rights-respecting functions into how their positions are executed. A rapidly building body of literature examining the boomerang effect on related phenomena has come to define how human rights are introduced and sustained in otherwise uncooperative countries (Brysk, 1993; Keck \& Sikkink, 1998; Lutz \& Sikkink, 2000; Brown, 2002; Sikkink, 2008; Koo \& Ramirez, 2009). Koo and Ramirez (2009) found that the neo-realist perspective largely fails to predict the advancement of rights specifically via the establishment of ombudsman offices and human rights treaty 
ratifications. Standard state-level variables such as GDP, developed vs. developing, democratic transition, and human rights records are less important than the growing saturation of the world with human rights norms, hosting global human rights conferences, and linking to the global polity. Such findings appear on the surface to corroborate the overarching notion that human rights in the post-Cold War world are bound more than ever to transnational global norms. Thus, either states do not act solely out of self-preservation, or acts of self-preservation themselves include public recognition of human rights norms on less tangible level. Lutz and Sikkink note that the global democracy wave of the 1980s has effectively realized much of that rights discourse throughout the region, particularly in light of the formation of the Organization of American States (OAS) and its charter prohibiting human rights abuses that were widespread until democratization. Examining the observed incidences of torture, forced disappearance, and non-democracy, all three incident types went from "very high" occurrences to medium (in the case of torture) and low (for the other two) from the late 1970s to the mid-1990s (p. 638). OAS captured the primordial human rights groups built upon an emergent discourse of human rights with respect to forced disappearances and children's rights, along with the aid of the foreign policy priorities of the Carter administration, led to a cascade that built enough momentum to withstand the reversal of fortune brought on by the Reagan administration and resurgent Cold War ideology. Argentina, in particular, has been focused on for this purpose (Brysk, 1993; Sikkink, 2008), with the same general theme of domestic, grassroots human rights actors receiving 
substantive aid from more equipped states and international non-governmental organizations (INGOs).

The subset of literature on the expansion of rights in the post-War world strongly suggests that some manner of increasingly interconnected politics and discourse diffusing across traditional state boundaries is more important than ever before. The boomerang effect and spiral model, after outlining the rapid development of Argentina as a liberal democracy emerging from pariah state status, rest on the assumption that global human rights norms themselves can and do lead to direct pressure on the part of intransigent states. This stands in contrast to the long-held realist assumption of states acting in a strictly rational fashion, responding to economic incentives and attempting to selfpreserve. Because there is little evidence that the countries in Latin America which have so far shown the most progress in respecting and protecting LGBT rights did so out of such concerns, another explanation must be given. I thereby hypothesize in part that these countries have responded to less material pressures, more in line with the boomerang and spiral models than anything else.

Some academic work explaining the progression of LGBT rights in Latin America has already been conducted, though it is limited relative to that which has been conducted for much of the developed world, particularly the U.S. Thus far we have seen full same-sex marriage achieved legislatively in Argentina, judicially in Brazil, along with wide disparities across the rest of the continent with respect to LGBT rights indicators. Same-sex marriage along with anti-discrimination measures have been 
enacted legislatively and presidentially approved in Uruguay, while a continuing disparity in the age of consent exists in Paraguay.

\section{Defining LGBT Rights: Beyond a Single, Concrete Policy}

The purpose of this project is to determine which variables are most relevant to bringing forth rights for lesbians, gays, bisexuals, and transgender (LGBT) individuals in regions of the world that are generally considered to be outside the realm of developed countries. In light of the fact that, on a regional basis, the most substantial progress seen for LGBT rights thus far outside the developed world is in Latin America. This having been said, there is nevertheless a conspicuous disparity throughout the region. Due to the relative homogeneity of culture, religion, economic indicators, institutional structure, and levels of democracy - the usual baseline variables toward which an analyst would turn before examining anything more subtle or complex - there are evidently other factors at play. With respect to the development of a systematic and rigorous analysis of the phenomenon, the ability to effectively hold the aforementioned variables constant will allow us to develop a comparative framework through which we may test the relevant hypotheses. Thus, while the enactment of policies is one matter, but the Latin American region has less disparity today in another crucially important realm than in that of LGBT policy success - rampant discrimination and even violence of LGBT people. The aim here is to illustrate that it is not necessarily the case that state behavior with respect to human rights matters mirrors or follows the attitudes of society at large. This is an important factor in the study in that it shows why alternative variables, e.g. international 
norm diffusion or pressure from NGOs and other interest groups, must play a substantial role in the progress seen on the policy front in those countries that have seen it so far. On the Social-Legal Disparity in General

A host of examples in recent world history point to a bidirectional process of civil rights expansions. Among the most notable may be the American Civil Rights movement of the 1950 s and ' 60 s which sought to end racial segregation in the South. Although the landmark decision Brown v. Board of Education occurred in 1954, segregation remained throughout the South in defiance of the ruling, courtesy of a well-entrenched status quo which had grown accustomed to segregated facilities and services. Although African Americans were now legally protected on the federal level, state and local governments became resistant to the point of requiring President Eisenhower to send the National Guard to Little Rock, Arkansas to oversee a safe desegregation of their public schools. Among the most notorious instances of violence directed towards civil rights protesters occurred in Birmingham, Alabama in 1963, wherein police cracked down on marchers by pummeling them with night sticks and high-pressure fire hoses. Such laws as the Fair Housing Act of 1968, the Community Reinvestment Act of 1977, affirmative action, and school busing arrangements in most major metropolitan areas in the late 1960s and ' $70 \mathrm{~s}$ were all policy goals that were hardly even conceivable as late as the 1950s. Nonetheless, the growing discontent on the part of minorities in being effectively barred from sharing in post-WWII prosperity combined with such effective and charismatic leaders as Martin Luther King, Jr., Bayard Rustin, and Andrew Young propelled the legal recognition of 
equality past what society was ready to accept. The aforementioned laws passed in the movement's wake, however, were swiftly met with all manner of backlash ranging from violence directed at civil rights volunteers and lynchings to much more subtle forms of protests such as enrolling children in private schools and redlining. In short, those favoring the racial status quo took significant strides to preserve the privilege that they enjoyed during the pre-Civil Rights era.

While this parallel is instructive in examining other civil rights causes, including those pushing for LGBT rights specifically, there are some notable distinctions that need to be drawn. For one, race is clearly visible and cannot be concealed or hidden, whereas sexuality can be selectively concealed by staying in "the closet." Relating to this, the assumption about homosexual activity for centuries and across cultures has been that it stems not from an innate characteristic, but from a primal desire that resides in everyone and is to be suppressed. As such, the concept of LGBT rights as a form of civil rights was inconceivable until quite recently. It was only when the push for an LGBT identity started bearing fruit that LGBT rights became feasible. In addition, racism, especially in the United States, has a history of serving as the status quo in one form or another for centuries, whereas discrimination or prejudice based on sexuality has only become a salient issue within the past few decades. Finally, while the expansion of equal rights to housing, schools, and employment for racial minorities spurred a backlash due in part to the perception that Whites would be crowded out of a zero-sum marketplace, a similar expansion of rights for LGBT people does not lend itself to any such perception: There are much fewer LGBT people than there are racial minorities in the southern or urban 
United States, and LGBT people are already afforded equal opportunity for the most part, though this is contingent on whether or not such people decide to stay in "the closet" in certain places. Aside from these differences, however, LGBT rights has overwhelmingly been framed by the most successful civil society actors as a civil rights or human rights issue, and thus there are inevitably at least some parallels that can be drawn to other civil rights movements.

The chief parallel that one can draw between civil rights movements of many different stripes lies in the fissure that often exists between recognition and protection from the state on one hand, and the attitudes held by the general public on the other. Whereas Brown v. Board of Education mandates a de jure desegregation of public schools, it took more than a decade for a de facto desegregation to occur in most Southern states. Trends such as these are a testament to the power of social forces independent of the state to reinforce status quo patterns of bias and to hinder substantive progress for civil rights generally.

Legal vs. Real for LGBT People in the Developed World

The legal-vs.-real phenomenon manifests itself in the LGBT arena in a few key ways. Perhaps the most intriguing manifestation of this, particularly for our purposes, is in the ways in which existing laws and protections often fail to protect LGBT individuals. For example, Jeff Gruenewald (2012) discovered that homicides committed against LGBT individuals are fundamentally different in nature, on average, than are those committed in general. Hate crimes or bias crimes of this nature often harm not only the immediate victim. Because the attacks tend to be reported widely as a crime specifically 
motivated by prejudice towards the individual based on the characteristic, it reverberates throughout the LGBT community and leads to widespread psychological damage as well. In this analysis of hate crimes in the U.S., other notable differences are that perpetrators tend to be much whiter and younger than homicide offenders as a whole, and these crimes are much more likely to be committed by multiple assailants rather than an individual committing a shooting (Gruenewald, 2012). Furthermore, the observation period during which Gruenewald pulled the data showed a substantial increase in antiLGBT homicides, further suggesting that a backlash to increased LGBT visibility, increased willingness of police to report such crimes as hate crimes, or some combination of both are responsible. Donald Haider-Markel (2002), in focusing on the response of police precincts across the U.S. to hate crimes legislation, discovered that police are likelier to focus more resources on hate crime prevention if police staff tend to support the enactment of such policies, the public being served supports such policies, hate crimes are particularly prevalent in the jurisdiction being served, and funding and training aimed specifically at hate crimes. In addition, large, metropolitan cities are much likelier to have task forces or otherwise more generous resource allocation to combating hate crimes than are smaller jurisdictions - a fact that aligns at least partially with the populace preference, considering the relatively cosmopolitan nature of such urban centers. One other noteworthy finding here is that the political preferences of elites and elected officials within the jurisdiction do not correlate with enforcement of hate crimes laws as much as the attitudes of the administrative bureaucrats do (Haider-Markel, 2002). In essence, we see that both the public at large and administrative officials influence 
treatment of hate crimes, and that the nature of such crimes is often fundamentally different from more generalized crimes.

Sari Dworkin and Huso Yi (2003) examine the more psychological aspects of what drives hate crimes. Dworkin and Yi make the point that, at least as of their report, virtually every culture in the world subconsciously instills the notion that heterosexuality is the exclusive normal with respect to sexual practices and familiar structuration. This phenomenon is more pronounced in developing countries that lack democratic institutions or liberal traditions, but tends to be instilled in the younger population in liberal democracies as well. Dworkin and Yi conclude in part that although most hate crimes are effectively already prohibited both by international laws targeting abuse and domestic laws in a vast majority of countries, these subconscious biases tend to correlate to less sensitivity to the plight of LGBT-identified individuals, furthering the disparity between countries in protecting their LGBT populations.

One other concept that helps illustrate the nuances of homophobic attitudes is that of covering, as conceptualized by Kenji Yoshino (2006). Laying the concept out in the context of a three-stage progression, Yoshino outlines the cultural shift of the past few decades that started with demands that LGBT people convert to heterosexuality, followed by demands for passing, and then for demands of covering. In essence, societal demands of conversion lasted for virtually the entire of modern Western history and much of history prior, and it rested on the assumption that homosexuality is a vice that ought to be overcome and suppressed. Homosexuality was generally classified as a mental illness during this period, and forced conversion therapy on the part of the state was not unheard 
of in much of the world. Once the idea of LGBT identity as an inherent characteristic, therefore qualifying as a civil rights issue in the 1960s and '70s, the cultural norms shifted away from the old assumptions based on homosexuality as a choice and instead placed demands on LGBT to "pass" as straight, meaning that one should make any effort necessary to refrain from exhibiting behavior that suggests LGBT identity, and to otherwise remain in "the closet" while anywhere in the public sphere. Starting in the 1990s or so, LGBT civil rights gained more traction and more people came to know LGBT people personally due to more people "coming out." Acceptance of LGBT identity started to solidify and it became acceptable to be "out" as an LGBT person. In spite of this, there are still unwritten double standards placed on LGBT people and couples, as demonstrated in the widespread perception that common public gestures of affection such as hand-holding and kissing are acts of "flaunting." In addition, one should refrain from openly discussing affiliation with LGBT advocacy groups and to keep discussions of same-sex partners to a minimum while around heterosexual people (Yoshino, 2006). In short, we should take note of the fact that (A) collective pushes for civil rights in general have had to overcome deeply-entrenched biases that often stubbornly remain even after formal, legal protections are put in place; and (B) the LGBT rights movement is presently in the stage of working toward ameliorating the leftover biases and prejudices now that basic formal protections have been put in place as per Lawrence v. Texas, the repeal of "Don't Ask, Don't Tell," et al. There remain disparities across the U.S. in terms of the extent to which rights are recognized and protected, and even the passage of laws are not enough to ensure that hate crimes legislation, for example, is enforced. The 
attitudes of society at large cannot be separated from the effectiveness of legal protections, nor is the legal arena sufficient in fully realizing the wellbeing of stigmatized and historically oppressed populations. To legally protect a long-stigmatized group such as the LGBT community, laws combating discrimination and hate crimes are evidently necessary pieces of the overall puzzle.

The Environment as it Currently Stands for LGBT People in South America

Grupo Gay da Bahia released a report in 2010 which documented at least 3,196 anti-LGBT murders between 1980 and 2009, suggesting what amounts to an epidemic ("Violence against LGBTs," 2014). The problem has become so acute in Brazil, for example, that a local Workers' Party representative in São Paulo has suggested that a specialized police force be created to combat anti-LGBT violence specifically, complete with training in counseling and human rights. The preliminary title of this unit is Delegacia Gay, as it would be modeled on a similar police force called Delegacia da Mulher ("Women's Precinct") (Avery, 2012; Jebsen, 2012). A number of other lawmakers in various levels of government have pushed for education reforms to be put in place so as to increase toleration. Among the most vivid and well-known recent examples of this phenomenon occurred in 2011, when a young man walking with a pair of gay friends through the heart of São Paulo's financial district was attacked by a small group of assailants who crushed a fluorescent light bulb over his face (Jebsen, 2012). In response to this, Telma da Souza - the lawmaker who suggested that the Delegacia Gay be established - said in a call for a national debate on the problem, "This should not be occurring in the 21 st century. We are not talking about gay rights here, but human rights" 
(Souza, qtd. in Jebsen, 2012). It may be useful to note that this last plea can be easily placed within the context of the civil rights groups mentioned in the previous section, giving at least some credence to the civil rights frame.

The arisal of the AIDS pandemic in the early 1980s demonstrates the divergence of social and state treatment of LGBT people. Jim Wilets (2011) notes that Brazil, like most of the rest of South America, saw sodomy laws repealed in the early $19^{\text {th }}$ century, as Spanish and Portuguese penal codes were notably less harsh on the matter than was the British penal code, thereby setting a legal precedent that has been relatively favorable to LGBT interests. In light of this, coupled with the lack of an official state church to steer policy, Brazilian lawmakers in the 1980s found the targeting of HIV/AIDS relief to the LGBT community a relatively straightforward and feasible approach to attacking the issue. Further, this approach was cemented by the relative support offered by the Brazilian military - a stark contrast to the juntas ruling Argentina and Chile around that time - and this was due at least in part to the cycle of democratic transitions and military governments that pockmarked the country throughout the $20^{\text {th }}$ century.

With a strong tradition of machismo, combined with a floundering civil society wrecked by transient governments of radically different natures, however, murders of LGBT persons in the country spiked, and such has been the case more-or-less consistently ever since. To make matters worse, police were often party to these attacks. With an on-the-ground response as unfavorable as this, the LGBT movement as a whole had decided to take their tactics underground, thereby still lobbying legislators for protections and other rights, but with as little visibility as possible. What one can take 
away from this is that the Brazilian case has by and large provided evidence that although open-ended institutions do not guarantee a tolerant civil society, it nevertheless shows that supportive institutions can sustain themselves and serve the needs of an otherwise widely stigmatized group.

The disparity in legal protections of LGBT persons throughout Latin America cannot be explained wholly by differences in social attitudes. But as seen in Brazil and Argentina, for example, the existence of exploitable political opportunities such as a government or other institutions committed to equal treatment as a principle, combined with sufficiently savvy social movement actors who are willing and able to exploit these loopholes, can overcome social prejudices and win some amount of legal progress and protection. This may only go so far when concerning the issues of rising violence committed toward LGBT persons, but the practice is not wholly separate from the issue, either. 


\section{CHAPTER III \\ PRELIMINARY CASE STUDIES}

The Social Movement Process

When focusing on the development of LGBT rights in South America, most of the focus is on the period following democratization, which generally took place throughout the 1980s. However, some primordial LGBT-oriented groups and social movements formed as early as the late 1960s, so it would not be sufficient to focus solely on the postdemocratization period when tracing the development of rights. I conceptualize the process in three stages: (1) emergence and identity formation, (2) movement toward inclusion, and (3) identity synthesis.

Emergence and Identity Formation

The period preceding democratization was defined in large part by systematic human rights violations and abuses, with practices ranging from torture, arbitrary and extrajudicial incarceration, forced disappearance, and exile of dissidents. Because even basic human rights were often disregarded, concepts of civil rights or minority protection were inconceivable. Nevertheless, as is often the case under such regimes, an extensive underground network of human rights advocates proliferated throughout this period. Some groups such as the OAS take a generalist approach, while others take on more 
specialized issues, among the most notable of which would be the children's rights movement in Brazil for its forthright role in exposing the abuses of the military government there.

Edward Cleary (1997) lays out four overarching factors responsible for the "explosion" of human rights across the region. For one, a broad social breakdown occurred in the period immediately following democratization, complete with deteriorating material living standards for a majority of residents along with frustratingly slow progress in the encouragement by governments to participate in political matters. Secondly, more cosmopolitan views of human rights had taken hold, largely with the Catholic Church serving as a vehicle, specifically with the advent of Mother Teresa and liberation theology. Thirdly, relating somewhat to the first factor, frustration with the corruption and bureaucratic obstruction of state institutions meant that enforcement of new human rights norms were all too often unrealized. Finally, an infusion of influence from developed countries such as the U.S. and several Western European nations, particularly Spain, took hold (p. 64-6).

It stands to reason that an upwelling of civil society and particularly of human rights recognition would be an ideal time for the emergence of previously avant-garde issues such as LGBT rights. LGBT-oriented movements did indeed become more prominent at this time, but to understand how they arrived even at that point, it proves necessary to begin even earlier. Stephen Brown points out that the first explicitly LGBToriented group to be founded in Latin America was the Argentinian Grupo Nuestro Mundo (Our World Group) in Buenos Aires in 1969. Two years later, a more radical 
group formed by some Grupo members and a loose coalition of leftist university students assembled Frente de Liberación Homosexual (Homosexual Liberation Front), which served as a clandestine group collaborating with various women's and workers' rights groups until it was forced into dissolution in 1976 by the military junta. During this regime, an estimated four hundred or so gays and lesbians were murdered alongside the more notorious sweep of forced disappearances. Following the junta, gay and lesbian life "flourished," and by the early 1990s, President Carlos Menem was pressured and shamed by U.S. activists during a state visit to grant legal recognition to CHA, which had been formed as the preeminent LGBT rights organization in Argentina following the arrest of over 200 gay men in a Buenos Aires bar in 1983 (Brown, 2002, p. 88). ${ }^{1}$

Fast-forwarding quickly to the $21^{\text {st }}$ century, it becomes clear that not all LGBT rights advocates necessarily strive toward the same goals, as the relatively recent ${ }^{2}$ FALGBT, an umbrella organization consisting of several independent groups, has emphasized partner recognition while CHA has traditionally sought a broader based of rights, e.g. adoption, eliminating discrimination in employment, HIV/AIDS activism, et al (Schulenberg, 2012).

While examining the emergence of the LGBT rights movement and discourse in the region, one other country warranting more extensive focus is Brazil. James Green (1994) illustrates that, like the advocacy groups which first emerged in Argentina, Brazilian advocates first organized while an undemocratic and illiberal military regime

\footnotetext{
${ }^{1}$ The significance of legal recognition in this context is that it permits such actions as fundraising or taking official positions. What is more, prior to its recognition, the Argentinian Supreme Court defended the lack of legal status based on Catholic teachings (Brown, 2002, p. 90).

${ }^{2}$ FALGBT formed in 2006 (Schulenberg, 2012).
} 
was still in place. Although gay bars and other catering venues appeared as early as the late 1950s when rural peasants migrated en masse to cities, the first reported LGBToriented groups to organize were in 1978 and ' 79 under the guise of Nucleo de Ação pelos Direitos dos Homossexuais (Action Nucleus for Homosexuals' Rights). The primary activity of NADH consisted of publishing and distributing a tabloid entitled $O$ Lampião da Esquina (Streetlight), though there were other street-based events organized on a regular basis. The inclusion of the term "homosexuals" in the name drew a great deal of controversy and ire both within the movement and among the public at large, primarily stemming from fears that too explicit and agenda was advertised - a potentially problematic transgression under a military regime. The more cautious members pushed for the label Somos to pay homage to the publication released by pioneering FLH in Argentina, but a compromise was reach in 1979 to adopt the label Somos: Grupo de Afirmaçao Homosexual (SGHA). The following year, an unprecedented protest took place in which various left-wing groups took to the streets in the country's industrial center, with SGHA members chanting, "Down with repression, more love and desire!" (qtd. in Green, 1994, p. 71). Due to various intra-movement squabbles, combined with a rapidly declining sense of urgency courtesy of democratization in 1985, the movement became dormant and nearly dissolved completely by 1995 when the International Gay and Lesbian Association (ILGA) hosted their international conference in Rio de Janeiro, having been summoned by an invitation by what had become the preeminent LGBT rights group in Brazil, Grupo Gay da Bahia. 
Although the proverbial seeds of LGBT rights activism were largely planted in Argentina and Brazil, other countries in the region have shown signs of emergence. In Chile, for example, a series of HIV/AIDS-combating groups formed in the late 1980s, while Movimiento de Integración y Liberación Homosexual (Movilh) formed separately in 1991 post-Pinochet to promote gay empowerment. Because of this fragmentation and structural weakness, Tim Frasca hypothesizes that legal progress has been blunted relative to that seen in other countries such as Argentina and Uruguay (2005). A largely disparate network of activists nearly succeeded in including an anti-discrimination clause in the Venezuelan constitution of 1999, but it was struck down at the last minute by local Catholic authorities (Merentes, 2000). Broadly speaking, there have been at least some efforts and at least some level of organization in virtually every country in the region, but strategies, tactics, and priorities can and often do differ.

\section{Factionalization}

Upon maturing in the 1980s into the mid-1990s, a number of rifts and disagreements tended to form within and between LGBT groups. Stephen Brown (2002) points to three categories into which advocates tend to fall: assimilationist, civil rightsbased, and radical. Assimilationist organizations emphasize the status of LGBT persons as citizens and as equals who are entitled to the same rights as everyone else, thereby justifying the expansion of partnership recognition or marriage on the grounds that it is necessary for the fulfillment of rights that have already been guaranteed by the state and/or society. ${ }^{3}$ Tactically, assimilationists are the most likely to emphasize the use of court cases as a stair-stepping process toward equality. Civil rights-based groups, like

\footnotetext{
${ }^{3}$ For more in-depth reading on this matter, see Sullivan, 1995.
} 
assimilationists, tend to normalize homosexuality in the public consciousness, but unlike them advocate in favor of a "different-but-equal" framing (Brown, 2002, p. 93-4). Civil rights framers will acknowledge that fundamental differences do exist which require some form of special accommodation, e.g. focus with respect to HIV/AIDS treatment or hate crimes laws to protect from social violence. Finally, radical framers claim that the currently existing models for sexuality as black-and-white traits that are unmalleable is too simplistic and restrictive. These avant-garde activists assume that sexuality is more fluid and complicated than its mainstream presentation suggests, claiming that openly LGBT people have instead embraced a potential that exists within everyone to some degree. ${ }^{4}$ Examples of each type along with their tactics have appeared in Latin American LGBT social movements.

Among the most prominent assimilationist organizations promoting LGBT rights in Latin America, CHA and Sociedad de Integración Gay-Lésbica Argentina (SIGLA) and ABLGBTT in Brazil are perhaps most illustrative. For instance, CHA has long been at the forefront of the broader push for incremental changes in that country, primarily through the courts. Likewise, ABLGBTT is the umbrella organization in Brazil that pushed for the long series of judicial battles beginning with claims to material benefits for partners and culminating in same-sex marriage (see Moreira, 2012)). More generally, as Brown states, assimilationist groups are the most inclined to interact with the state and with larger human rights organizations, and conversely less inclined to interact with other activists and organizations (2002, p. 93). These groups tend to be the most pragmatic and

\footnotetext{
${ }^{4}$ For more in-depth reading on this matter, see Warner, 1999.
} 
results-oriented, there leading to potential conflicts with groups placing more emphasis on maintaining the identity or message behind the push to begin with.

Civil rights-based groups are exemplified in part by FALGBT - the other major player in in Argentina besides CHA - as well as Gays DC, the latter of which focuses as well on HIV/AIDS issues in Buenos Aires. FALGBT is an umbrella organization which is comprised of several preexisting organizations, many of which had somewhat differing priorities, but one of the most common themes among them is a skepticism and even aversion to the state, given its historically oppressive capacity to imprison and brutalize (Brown, 2002, 94). FALGBT is adamant in its insistence on realizing the passage of antidiscrimination protections specifically for LGBT people, whereas Gays DC likewise pushed for state-appointed legal aid for HIV-positive individuals who have suffered concrete discrimination. In each of these cases, it follows that the state must recognize a fundamental distinction that exists between the LGBT populace and everyone else, since the discrimination in question is claimed to be unique to that population. Nevertheless, FALGBT is also the organization which pushed for same-sex marriage in the Argentinian Congress (see Schulenberg, 2012, forthcoming). In this sense, the assimilationist and civil rights-based activists are not mutually exclusive, as both tend to favor some form of state recognition and equality of legal protection. The key difference lies in which approach is presumed best to accomplish this.

Radical LGBT activists, in sharp contrast to the other two categories, reject such labels as "homosexual" or "lesbian" as character descriptions, instead basing all strategies and goals on the assumption that oppression of LGBT rights comes in the form of 
socially-enforced suppression of the homosexuality that exists within everyone. Further, this type of oppression is intricately linked, radical activists assert, to all other forms of oppression that exist as an inevitable consequence of a capitalistic social order. As a result, radicals often find themselves profoundly at odds with civil rights advocates and especially with assimilationists, with the latter sometimes being viewed as even worse than the police, state, and other oppressive agents, given their role as insiders. Among the most active such groups is the FLH, who notably claimed that existing rights discourse affords nothing of value to difference, given its assumptions of universality, and have consistently criticized CHA for ceding short-term tolerance for long-term identity maintenance, and have consistently criticized CHA for conceding long-term social recalibration in favor of short-term tolerance (Brown, 2002, p. 95). By and large, at least as far as policies achievements are concerned, radical groups are now largely absent as cohesive LGBT rights advocates. This is likely due on the one hand to the inherent difficulty of maintaining a distinctive identity while denouncing the very existence of such a fixed identity in the first place, and on the other hand to the concrete policy victories seen by such groups as ABLGBTT and FALGBT.

The movement in Brazil during the factionalization stage was marked by a dearth of activism in general due to the onset of democracy and the widespread presumption of liberalization and an auto-piloted restoration of civil liberties. This was also, as seen in Argentina, a period of lacking cohesion among activists and of infighting within groups. Indeed, given the sheer size along with the political structure of the country, it might only stand to reason that fragmentation of some form is inevitable. Despite all of this, Grupo 
Gay da Bahia spearheaded a successful national campaign to gain legal recognition from the federal government in 1988, which spurred a renewal in the movement as a whole (Green, 1994). At around the same time, the AIDS crisis had peaked, thereby providing additional fuel to encourage renewed vigor for LGBT rights activism. One other factor that effectively forced the dormant movement out of its lull was an alarming and unexpected rise in violence committed against visibly LGBT persons, particularly gay and effeminate men. While this did not necessarily lead to a coalescence of advocacy groups within the country, it did at the very least demonstrate a need for and benefits of taking a more positive role expand and solidify rights.

\section{Identity Synthesis}

Although a specific time frame is difficult to pin down, the recent policy successes in at least some countries within the region are attributable in large part to developments that occurred in the mid-to-late 1990s. It was at this time when LGBT rights groups in the region had begun to connect in a substantial way to the global community, which in turn provided activists with resources, both material and strategic, that had never even been conceived before. In 1995 when ILGA decided to host their annual conference on global LGBT rights in Rio de Janeiro. The significance of this, in a nutshell, is that it represents a break point at which the boundaries of nation-state and norms of the region were being transcended, leading to a reinvigorated movement first in Brazil, then in Argentina, then followed by the rest of the region, however unevenly.

The upcoming case studies will cover the contemporary affairs of the South American LGBT rights movements in much greater detail, but prior to that, it is helpful 
to keep the following in developments in mind as they have unfolded during this stage: First, there has been a general movement in the direction of greater cohesion, perhaps most visible in the formation of ABLGBTT in Brazil and FALGBT in Argentina. Secondly, the framing of the issues have likewise coalesced, moving from the tripartite fragmentation found during the factionalization period immediately preceding and immediately following democratization. The radical factions have largely dissolved or collapsed into the new umbrella organizations, presumably due to pressure from the infusion of liberal norms from the international realm, and perhaps related to the parallel developments seen in left-wing political parties throughout the region excepting Venezuela and Bolivia. Finally, it is not until the synthesis period that we have seen concrete policy objectives being realized in the form of partnership recognition and antidiscrimination legislation. This does not necessarily imply that similar progress in the realm of civil society and the attitudes of the public, as the continuing scourge of antiLGBT violence in Brazil starkly shows. Nevertheless, the recent period of activism has shown a definitive acceleration of concessions on the part of the state in those countries that have been most receptive to civil society and to emerging global norms.

In countries that have seen at least a handful of social movements pushing specifically for LGBT rights since prior to democratization, there is a greater likelihood that such countries will have larger and more cohesive umbrella organizations that direct LGBT interests to a common goal. Because of this common goal and funneling of available resources to that goal or set of goals, it stands to reason that countries with consolidated interest groups will see much greater likelihood of policy passage and/or 
positive court rulings. The international norm diffusion literature (Keck \& Sikkink, 1998;

Risse \& Sikkink, 1999; Lutz \& Sikkink, 2002; Murdie \& Davis, 2012; Holzhacker, 2013) strongly suggests that human rights norms tend to be introduced to developing countries via effects such as the boomerang and spiral models. These are in turn carried out by domestic actors whose success is contingent on their size, wealth, and cohesiveness.

\section{Argentina and the Spanish Precedent}

Examining the case of Argentina more closely, Shawn Schulenberg (2012) laid out comprehensive description of the events and actors which took place leading up to the enactment of same-sex marriage in 2010. First, one should be careful to distinguish between constitutional and civil law in this context, as the former is ambiguous, stating that "The private actions of men which in no way offend public order or morality, nor injure a third party, only reserved to God and are exempted from the authority of judges" (Constitución de la Nación Argentina, 1994). Civil law is much more straightforward in regulating marriage as between a man and a woman only, as per Article 172 of the Argentine Civil Code (Código Civil de Argentina). The judiciary in general and the Supreme Court in particular are very reluctant to rule in a manner that might be perceived as either nullifying existing law or violating the wishes of the president who enacted them. Because of this, a series of unsuccessful court cases throughout most of the first decade of the new millennium gave way in 2009 to a ruling by an administrative judge in Buenos Aires which granted full marriage rights to same-sex couples. The administrative judge in the Buenos Aires ruling reasoned that because the constitution for the 
independent city of Buenos Aires explicitly prohibits any discrimination on the basis of sexual orientation, any provisions on the federal level which dictated otherwise proves unconstitutional as far as the city was concerned. What is more, the generally conservative mayor at the time expressly stated that he would not appeal the ruling (Schulenburg, 2012, p. 114-5). This was a truly groundbreaking decision, as it clearly led to a cascade of much further-reaching demands.

This evidently led to a flood of judges willing to publicly step up and speak in favor of such unions, as four other cases were ruled affirmatively within the next year (Schulenburg, 2012, p. 115-6). The executive branch, namely President Cristina Fernández de Kirchner, began to speak passionately in favor of same-sex marriage that year as well, presumably because of the pressure that built from the recent cascade of positive rulings in courts throughout the country combined with additional pressure from one particular arm of the executive branch - the National Institute Against Discrimination, Xenophobia, and Racism (INADI) (p. 117-8).

Finally, in the legislative branch, thanks in no small part to the vocal support of the President, a law recognizing same-sex marriage nationwide successfully passed. This happened in light of the fact that the Justicialist Party - the party to which Fernandez de Kirchner belongs - held a majority in the legislature that year as well. Further, because political parties in Argentina tend to be very deferential to their leaders, it stood to reason that Justicialist legislators would quickly fall in line, and with additional lobbying by activist groups, they did precisely that (p. 119-22). These are, in essence, the institutional factors at play. Cruz reasons that activists pursued change through the legislature in 
Argentina due to the Argentine judiciary's history of utilizing "Catholic ethics," in addition to the evidently lopsided nature of the way in which standing is granted to different parties: In order to challenge a same-sex union in court, one need simply be a "concerned citizen," whereas one must rigorously prove that they are in a relationship whose stature vis-à-vis the state leads to sufficient hardship (p. 334-5, 351). With these factors taken into account, we can undoubtedly say that LGBT rights advocates would do well to pursue their interests through the legislature and to gain support from the President in order to succeed.

Aside from institutional factors, influence came from elsewhere. The literature strongly suggests that influence from outside the country's borders played a substantial role as well (Brown, 2002; Piatti-Crocker, 2010; Friedman, 2012; Bonomo, 2013). Brown (2002), for example, notes that a combination of factors including the return to democratic rule, the rapid dissemination of a human rights-centric discourse, and a measure of international support all coalesced in Argentina as early as the 1980s so as to create a foundation favorable to the successes seen decades later. This conclusion can be reached, Brown argues, by viewing LGBT activism in Argentina through the politicalopportunity-structures lens. Breaking LGBT rights movements down into three broadlydefined groups - identity-based, civil rights-based, and radical - Brown notes that up to that point, those framing the issue in a civil rights fashion proved most successful as far as policy concessions are concerned, at least in Buenos Aires. Meanwhile, the identityframing groups often clashed with the radicals as the former wished to achieve equality by means of eliminating any gendered language from marriage laws and generally 
eliminating the role of the state in regulating domestic affairs at all, whereas the former premised their grievances on their LGBT identities to being with. As such, the civil rights framers were able to take advantage of the aforementioned conditions in place and achieve concrete concessions from the state.

Citing the precedent of a system to establish quotas for women in the legislature in the 1990s, Piatti-Crocker (2010) contrasts the Argentine LGBT movement of the following decade from the quota movement by noting that it is and always has been relatively fragmented. In addition, mobilization occurred through a pattern of upward diffusion, beginning in the independent city of Buenos Aires along with a handful of other municipalities across the nation. This upward diffusion proved very slow and increasingly frustrating, so more aggressive pursuit of same-sex marriage legislation on the federal level had been adopted (FALGBT), which served as something of an umbrella group for a previously disparate network of activists (Piatti-Crocker, 2010, p. 52). Although the group which until then was most active - CHA - had been more cautious and pushed for civil unions, FALGBT along with the aid of INADI took cues from legislation in Spain and elsewhere in Europe to draft the marriage legislation that eventually became law (p. 53-4). The thesis here largely parallels that of Brown, with the added emphasis of being able to overcome opponents, namely the Catholic Church.

Friedman (2012) expands upon the international diffusion thesis by revealing that the Spanish government, in the wake of legalizing same-sex marriage there in 2005, financially backed activists groups across Latin America and particularly Argentina. This practice came with a great deal of precedent in that Spain has remained involved in the 
region in a number of ways, be it economic, political, or cultural, including in transitioning to democracy during the decade or so between the fall of Franco and the third wave of democratization. The Triangle Foundation, which emerged from the Franco dictatorship as a key LGBT rights promoter in Spain, was particularly well-connected to civil society groups in Argentina, effectively underwriting the efforts of CHA and later FALGBT with both financial support and legislative blueprints (Friedman, 2012). We may draw from this that the influence from abroad and particularly from Spanish government and civil society may actually have proven a necessary condition for the successful implementation of nationwide LGBT rights policies, as the finances and legislative precedent at the time was not self-evidently conducive to the successful enactment of such.

Bonomo notes that Argentina has historically been more broadly receptive to international developments, including those within the sociocultural realm. Examples aside from interaction with Spanish organizations include the successful lobbying by CHA of the Norwegian and American Red Cross organizations to provide substantial funding to AIDS research in Argentina (Bonomo, 2013). What is more, international human rights norms in addition to material resource diffusion has clearly made its way into Argentine civil society in all three branches of government along with its nongovernment organizations, ranging from a developing current of strict scrutiny in the federal judiciary to influencing civil society organizations to reframe their struggles in terms of human rights rather than on strictly identity-based claims or trying to radically alter the priorities of the state: The judiciary has reformed itself to treat LGBT rights 
more as a human rights issue in general, thereby creating a trajectory based on favorable rulings for survival benefits toward greater interpretation of LGBT rights as human rights (Saldivia, 2010). The influence on civil society groups such as CHA and FALGBT largely corroborates Brown's (2002) thesis. No doubt, Argentina has on the whole proven very receptive to international influence, particularly since democratization in the 1980 s.

\section{Judicial Innovation in Brazil}

With respect to Brazil, gaining progress through Congress is exceedingly difficult in light of its historical inability to pass anything unless there is a broad, nationwide consensus is shared. On top of this, as de la Cruz points out, there is little pooling of resources or engagement between the hundreds of LGBT activist groups throughout the country. A handful of disparate groups with comparatively more resources must effectively go it alone. Confronting these two obstacles, a handful of relatively influential activist groups developed a campaign of litigation on behalf of aggrieved samesex couples (de la Cruz, 2013). Thanks to the presence of unusually receptive Supreme Federal Court justices, the Court ruled in 2011 that civil unions must be recognized on the basis of constitutional rights for families, and this was expanded through the same avenue to full marriage two years later.

The Brazilian constitution is noted particularly for its heavy emphasis no only on individual but also on collective rights, as well as for its assignment of the Office of Public Prosecutor who wields unprecedented authority over the enforcement of constitutional duties and Brazilian public administration more generally. Another key 
aspect of the Brazilian constitution that proves uniquely influential in court rulings favoring same-sex couples ruling by the Supreme Federal Court that such couples fall under the guise of family units. This stems from a broader trend within Brazilian law in which unmarried couples, largely on the basis of the family-oriented rationale reached by the Supreme Federal Court, are granted de facto marriage rights regardless (Moreira, 2012). This suggests that Brazilian LGBT rights activists were not content merely with material guarantees - they instead continued pushing for identity-based rights, using the substantive guarantees granted them as a base on which to build a conceptual pyramid. This phenomenon may in fact shed light on why there has been less of a push for full marriage rights as we have seen in developed countries as well as in Argentina - as long as the same effective rights have already been granted, then why expend the resources on pushing for full de jure or full formal marriage rights? Moreira outlines a five-stage litigation process with respect to same-sex unions that has been largely unique to Brazil: (1) a demand for equal property and inheritance rights; (2) reacting to the struggles of entering the institutions which regulate domestic cohabitation; (3) a wave of lawsuits aimed at sanctioning gay rights as diffuse rights; (4) litigation up to the level of the Supreme Federal Court for the recognition of same-sex unions as stable unions; and (5) further litigation for converting said unions into full marriages (Moreira, 2012). This process will be further fleshed out in turn.

An increase in demands among same-sex couples for equal treatment with respect to property and inheritance served as the gateway through which future lawsuits revolving around same-sex marriage would follow. Particularly with respect to social 
security benefits, a series of lower-court rulings provided mixed decisions throughout the country in the early 2000s, culminating in a 2007 ruling by the Supreme Federal Court that the Brazilian constitution mandates equal protection of same-sex couples on these grounds (Moreira, 2012, p. 1021-4). Notably, given the unique emphasis on family rights, the constitution regulates cohabitation in a particularly rigorous fashion. Defining "stable unions" in an a priori fashion as heterosexual ones at first, the litigation wave of the early 2000s sought to roll same-sex unions into this definition. Prior to the aforementioned ruling, judges were effectively prohibited from analogizing same-sex and married couples, for the definition of "stable union" could now much more plausibly be extended to same-sex couples. This was expanded in light of a state court ruling in the Rio Grande do Sul which opened civil unions (and two years later, marriage) to same-sex couples there (p. 1025-8).

The concept of collective rights has been uniquely enshrined in the Brazilian constitution and has, in light of a lawsuit wave not unlike that engineered by FALGBT in Argentina, helped speed the process of folding individual same-sex rights into this process (p. 1030-5). Following these lawsuits, two offices - the Rio de Janeiro Solicitor and the Office of the Solicitor General - had been brought to court for illicitly recognizing same-sex unions as per federal law as it stood at the time. The Supreme Federal Court ruled in favor of the offices, disregarding precedent and instead expanding the 2004 Rio Grande do Sul ruling to the entire country in 2011 (p. 1036-7). Through the two years that followed, another series of mixed lower-court rulings ended up at the Supreme Federal Court, with full marriage rights being granted to same-sex couples in 
May 2013. It was ultimately decided that a distinction must be made between civil and religious marriages, since it was no longer the case that the Catholic Church was the sole arbiter of the institution as it had been in earlier years of the republic's existence (p. 1040-2). In sum, it is readily apparent that a sustained effort on the part of a loose, nationwide coalition of plaintiffs backed by key institutions such as the Office of the Solicitor General proved instrumental in facilitating a gradual progression toward full marriage rights afforded to same-sex couples on a national basis.

Why has progress with respect to LGBT rights been so heavily skewed toward the judiciary in Brazil? Political parties are not particularly well disciplined, nor are they as deferential to their leaders. As a result of this, it can be much more difficult to form enduring coalitions to push bills through the legislature. Furthermore, unlike in the case of Argentina and the nation's civil code does not neatly or definitively outline marriage as between a man and a woman, as established in Article 1,723: "The marriage takes place when a man and a woman express before a judge their willingness to establish conjugal ties, and a judge declares them married" (Código Civil de Brasil, translated by Schulenburg, 2010). In addition to this relatively weak phrasing, the Constitution explicitly states that the duties of a republic are to "promote the well-being of all, without prejudice as to origin, race, sex, age, and any other forms of discrimination" (Constitución da República Federativa do Brasil, tranlated by Schulenburg, 2010). Finally, it should be noted that President Luiz Inacio Lula da Silva was perhaps the most vocal advocate of same-sex marriage of any Latin American executive to date (Schulenburg, 2010). It rapidly becomes intuitive as to why the Supreme Federal Court 
reached the verdict that it did when considering the fact that Lula appointed nine of the eleven justices serving since 2010 (Jardim de Santa Cruz \& Garoupa, 2011). Given the events seen thus far, it would appear that the sluggishness of the Brazilian legislature has not stood in the way of LGBT rights activists.

The process in Brazil differed mainly in that it bypassed the legislative branch due in no small part to long-observed difficulties on the part of the Brazilian Congress to pass even laws which may have had wide coalitions of support, never minding relatively novel and niche interests such as same-sex union recognition. A number of movements, perhaps most notable among them being ABLGBTT and Grupo Gay da Bahía developed in the 1980s and '90s, not coincidently arising shortly after the rise of democracy. These movements have shown a very dynamic two-way relationship with international human rights norms when it comes to LGBT rights. As Christine Bonomo (2013) notes, Brazil has not only shown influence from, but it has in turn lent influence to, international legal norms with respect to LGBT rights.

This phenomenon can be traced back as far as 1995 when ILGA (International Lesbian and Gay Association) hosted its annual global conference in Rio de Janeiro. At that conference, a number of activists from developed countries in Western Europe along with the U.S. met with fledgling NGOs coordinators in Brazil and encouraged them to travel to their countries so as to see how organization and lobbying efforts are done there (Bonomo, 2013). After gaining resources, information, and general know-how from varied organizations applying different tactics, activists brought the tactics home and began to aggressively apply them there. On the state level, progress appeared in Rio 
Grande do Sul when a 2004 court ruling mandated that civil unions be recognized there, followed by a 2006 ruling in the same state mandating legal adoption for same-sex couples (Notary RS accept gay marriage registration, 2006). There are factors beyond the domestic realm which must be addressed as well, however.

In 2003, Brazil introduced the Resolution on Human Rights and Sexual Orientation to the U.N. Commission on Human Rights, the signatories of which consisted entirely of European and Commonwealth Realm countries in addition to the U.S. ${ }^{5}$ Among the most noteworthy aspects of this resolution are its second and third bullet items stating that the enjoyment of human rights "... should not be hindered in any way on the grounds of sexual orientation," and calling upon states to promote and protect the human rights of all persons regardless of their sexual orientation (Brazilian Resolution, 2003). Four years later, showing a commitment to this cause, the Brazilian delegation to the U.N. sponsored the Yogyakarta Principles. In essence, this doctrine seeks to extend preexisting human rights norms to the area of sexual orientation and gender identity, developed through a seminar in Yogyakarta, Indonesia by an international panel of human rights scholars and experts. The following year, yet another significant breakthrough had occurred in which Grupo Gay da Bahía successfully persuaded the federal government to hold a national LGBT rights conference in which policy ideas and concerns over the trend of rising antiLGBT violence throughout the country were addressed (Bonomo, 2013). Of course,

\footnotetext{
${ }^{5}$ Likely resulting in part from the aforementioned developments in addition to the widespread dissemination of predominately U.S. media covering the tail-end of the AIDS crisis, the debates leading up to the drafting and implementation of "Don't Ask, Don't Tell" and the Defense of Marriage Act, and the controversy surrounding the murder of openly gay Wyoming college student Matthew Shepard (Bonomo, 2013).
} 
statements and proposals at the U.N. and other international level do not by any means translate directly into domestic policy absent additional key players, hence the role of domestic civil society actors.

One area in the realm of LGBT rights that has met relatively limited success can be seen in the alarming headlines that have appeared as of late regarding an apparent spike in violence directed toward LGBT people. Although it is as yet impossible to say definitively, this does appear to be some form of backlash against the rapidly increasing visibility of the LGBT community stemming from the policy successes that they have won. There have already been attempts by Congress to stem the bloodshed, but it has been blocked by the country's powerful legislative block of evangelical Christian conservatives. Perhaps the most notable of these was proposed by senator and former mayor of São Paulo Marta Suplicy simply dubbed the Anti-Homophobia Law, and it would have effectively criminalized any public utterances against homosexuality. In light of growing frustration with continued failures in the Brazilian Congress, some notable initiatives have taken place on the local level, particularly in São Paulo where a specialized police force that would be named Delegacia Gay would be trained specifically to counteract anti-LGBT violence in the city (Avery, 2012; Jebsen, 2012). The broader lesson to taken from these developments is that mere legal recognition on the part of the state is not necessarily enough to protect from non-state aggressors. The quest for LGBT rights lies beyond the fight for same-sex marriage. 


\section{Developments for LGBT Rights in Other South American Countries}

While Argentina and Brazil have been by far the most thoroughly studied countries to date with respect to the development of LGBT rights, it is abundantly clear that this is a broader, regional phenomenon in many respects. It stands to reason that some level of diffusion would happen throughout the region as a whole, given the relative constancy of religion, socioeconomic indicators, political culture, and institutional structures which exist there. Although it does not yet garner as much focus as the pair of countries examined thus far, we will briefly account for some of them in turn.

Aside from Argentina and Brazil, there is one other federal republic on the continent Venezuela. This is worth pointing out because there appears to be some advantage in the ability of subnational entities to experiment with policies so that they might diffuse upward. As things presently stand, one Venezuelan state - Mérida - recognizes same-sex civil unions as of 2005. As per the upward diffusion hypothesis, one would expect for Venezuela to have seen more progress by now, but Mérida remains the only jurisdiction with any kind of recognition of LGBT rights. The blockage of anti-discrimination provisions in the 1999 constitution which coincided with the assumption of power by Hugo Chávez may provide some insight into this matter, though - although the Constitutional Commission was on the verge of including a clause to expressly forbid discrimination by public or private organizations nationwide, the Opus Dei branch of the powerful Catholic presence in the country convinced the head of the Commission, himself and Opus Dei member, to drop the provision (Merentes, 2010). In addition to the 
strength of the Catholic Church, it is also possible that the priorities of the government under Chávez have simply not prioritized action on this front.

In something of a contrast to Venezuela, the 2008 constitution of Ecuador includes a clause that mandates state recognition of same-sex civil unions, though it along with President Rafael Correas emphatically stopped short of endorsing full marriage equality. Before addressing this, it might be worth noting that the previous constitution, drafted in 1998, expressly prohibited discrimination on the grounds of sexual orientation. This was expanded and included civil union recognition in the most recent constitution, but a number of LGBT rights activists in the country have lamented that the explicit line drawn for marriage suggests a compromise made with its more conservative drafters, as well as with the Catholic and evangelical elements within the country. In particular, the governing party, Alianza PAIS, was split roughly in half with respect to LGBT rights, thereby suggesting that a compromise of sorts may be necessary in order to achieve any advancement at all, as well as to avoid and anti-LGBT backlash (Corrales, 2010). This reflects the leverage enjoyed by both sides of the split in question, and it dictated that more conservative voices on the drafting committee had just enough of it to ratchet down the final product.

In Chile, some interesting developments have taken place. First, it might be worth mentioning that the Chilean Senate is unique among legislative chambers both within and outside Latin America in that there is a panel of seats reserved for appointed legislators who were appointed by the outgoing Pinochet regime in the early 1990s (Frasca, 2005). There is debatably a very loose pair of coalitions which forms a de facto two-party 
system, but if there is, "party" discipline is very limited - more akin to that seen in Brazil rather than in Argentina. Given these developments, it is difficult to say why the status of LGBT rights legislation is where it is (very limited to nonexistent), but we might preliminarily hypothesize that similar problems persist as those in the Brazilian legislature. The formation of alliances is evidently very crucial in Chilean politics, as the party system is so transient. This likely explains why there have been no success to date in legislating same-sex union recognition, for instance, despite the fact that that there have been no fewer than four attempts within the past decade (Núñez González, 2010). Niche issues such as LGBT rights would have a difficult time passing through such a system, and the fact that the democratic transition took place later on in Chile may also serve as a hindrance.

Jordi Díez offers brief insight on the cases of Colombia and Peru. The judicial avenue has the avenue of choice there, and with some success if not as much as has been seen in Brazil. With a more restrictive constitution defining marriage explicitly as between a man and a woman as outlined in Article 42 of the constitution (Constitución Política de Colombia), combined with a perennially resistant legislature, the Constitutional Court has de facto ruled that same-sex civil unions must be recognized through a trio of rulings on pensions and social security inheritance rights in 2007, 2008, and 2011. In Peru, on the other hand, activist groups pursued the legislative route in light of the presence of an atrophied and deeply conservative court of last resort, but to no avail. This is almost certainly due at least in part to consistently low public approval of homosexuality in general (Díez, 2013). This helps to demonstrate the lack of uniformity 
across the continent despite the apparent presence of at least some impetus for LGBT rights in the region as a whole.

\section{Preliminary Conclusions}

From the work done thus far on the politics of LGBT rights in South America, we can note that one of the most important factors predicting the likelihood of progress on the LGBT rights front is how tightly or broadly a given country's constitution defines such concepts as marriage and individual rights. We have seen that in Brazil, for instance, litigators on behalf of aggrieved same-sex couples wielded the constitutional language establishing such substantive guarantees as Social Security and pension benefits to spouses to extend it to the partners of same-sex couples, which judges ruled was only necessary given the looseness of the language with respect to gender. This was subsequently seized upon to push for greater recognition of same-sex couples to the point of nationwide recognition of full same-sex marriage. Likewise in Colombia, aggrieved couples and their counsel were able to take advantage of the substantive guarantees provided for by the constitution to ensure that same-sex couples must have rights similar to married opposite-sex couples, if not officially recognized as such in the end.

Another predictive factor is the institutional framework with which advocates must cope, specifically the structure and discipline of the political parties, as well as those parties' relationship with the president. We saw in Argentina, for instance, that the ideal combination of party discipline and presidential support allowed for the same-sex 
marriage bill there to pass both chambers of Congress and proceed to be signed into law by the president. Brazil, in contrast, has yet to see any LGBT rights-oriented legislation pass its Congressional chambers despite the presence of a highly and outspokenly supportive president, and this undoubtedly stems from the lack of discipline seen within its party structure, as this has historically proven detrimental to the speed of and ability to pass laws focused on relatively niche interests. Tangentially related is the disposition of the judiciary in a given country. We have seen in Argentina, for example, that it is by and large much easier to challenge same-sex unions than it is to argue in favor of their recognition due both to structural factors as well as the use of Roman Catholic doctrine in court rulings. Those countries in which church and state are more decisively separated such as Brazil, Colombia, or Ecuador, the rationale for ruling against the recognition of same-sex couples or individuals is made seriously limited.

Third, the structure and prevalence of social movements evidently proves crucial to the success of LGBT rights policies in a given country. We have seen in Argentina for instance that a well-organized and cohesive umbrella front - FALGBT - had pursued an ambitious push for legislating full same-sex marriage on a nationwide basis, and such would not have been accomplished had it not been for the initial push by this or some other social movement force. The literature has suggested that more monolithic, centralized, and resource-equipped social movements will tend to focus more on agreedupon, consensus-framed issues rather than attempting to pursue a disparate set of different if not unrelated policy goals, as is evidently the case in Brazil (and the United States, for that matter). In addition to these domestic factors is the influence of 
international organizations and norms. Much of the impetus for the push for LGBT rights in Brazil stemmed from the coalescence of its primordial and fragmented activist groups at the 1995 of ILGA at Rio de Janeiro, whereupon organization leaders were invited to Spain and other European countries which had shown more progress on the LGBT rights policy front. Taking cues from them in areas ranging from organizational structure to policy templates. Additionally, it has been well-documented that the marriage legislation passed by the Argentine Congress drew generously from the legislation passed in Spain five years prior.

Finally, it is not possible to assess the feasibility of LGBT rights progression without accounting for the broader cultural context within which it takes place. Undoubtedly the most visible impediment to many goals set forth by LGBT rights advocates is the Catholic Church, and perhaps more generally, the cultural influence and sentiments generated by it. We have seen that the anti-discrimination provisions initially provided for in the 1999 Venezuelan constitution were ultimately struck down by Catholic opposition. Likewise in Argentina, Cardinal Jorge Bergoglio (now Pope Francis) led the opposition to the same-sex marriage bill that was in progress there, even though it ultimately passed despite this. Catholic opposition to explicitly including same-sex marriage in the 2008 Ecuadorian constitution dictated that they would have to settle for lesser civil unions instead. More broadly, public opinion data shows that there is a wide disparity between countries within the region with respect to favoring same-sex unions. 


\title{
CHAPTER IV \\ CONCEPTUAL FRAMEWORK AND HYPOTHESES
}

\author{
Constitutional Language \\ $H_{1}$ : The presence of a constitutional provision for unions or families will substantially \\ facilitate pro-LGBT policies if worded in a gender-neutral fashion, but hinder it if \\ gendered.
}

The language of a given country's constitution will help determine the feasibility of such policies as same-sex marriage and civil unions. On the one hand, if there is a provision that establishes a right to form and maintain a family, but without any mention to gender, it will be more difficult to deny equal access to such entitlements as social security benefits or pensions from same-sex partners than if no such language existed at all. On the other hand, it will be much more difficult to determine this to be the case if the constitution outlines such a right while also interjecting gendered language. This should be the case especially when dealing with judicial rulings one the matter, though to a lesser extent it should also be expected that legislation would be impacted by constitutions as well. Literature on the matter (Moreira, 2012; de la Cruz, 2013) has 
already hinted at this as a substantial factor, so it is appropriate to account for it in a systematic study of the phenomenon as well.

\section{Federalism}

$\mathrm{H}_{2}$ : LGBT rights policy is more likely to reach the federal level if state- or local-level experimentation has taken place.

With respect to policies stemming from relatively niche interests such as LGBT rights, abortion rights, drug legalization, lottery implementation, et al., the best way to gain traction tends to be by way of upward diffusion (Berry, 1994; Makse \& Volden, 2011; Riverstone-Newell, 2012; Shipan \& Volden, 2012). In essence, when precedent can be set at some level within a country or a state, the policy in question moves beyond a mere abstraction and can be judged based on its outcomes rather than on speculation, which is typically anchored in ideology and biases. Once the policy can be judged on a more concrete level, and assuming none of the perceived negative consequences come to pass, activist groups can make a more concerted push to expand the policy to the next federal level, or to the state level in the context of local policies, without nearly as much concern for ideologically-driven pushback.

\section{Social Movements}

$H_{3}$ : LGBT movements will prove more effective with greater overall cohesiveness along with linkages to international and Western organizations. 
Among the most important takeaways from the literature on social movements for LGBT rights in South America thus far is that the maturity and professionalization of a the organizational infrastructure within a given country matters a great deal as far as success in pressing for policy outcomes is concerned. Argentina had multiple and occasionally conflicting interests with CHA and its more conservative, assimilationist goals versus the myriad other groups which eventually formed into FALGBT, pushing for a more difference-conscious and accomodationist set of goals. Brazil, like its political parties, saw a very splintered landscape of LGBT rights groups with varying approaches and goals, but once ABLGBTT formed via the consolidation of GGB and dozens of other organizations, the resources of each group could be consolidated and directed in a more precise and streamlined fashion. Conversely, countries such as Peru or Venezuela may have several activist groups present, but their success has been limited relative to those with longer-standing and consolidated social movements. We should expect a significant positive correlation between movement consolidation and policy success.

\section{Institutional Factors}

$H_{4}:$ Greater presidential support for LGBT rights initiatives will correlate positively with successful passage whereas greater shares of a legislature with distinctly right-wing parties will correlate negatively.

As far as the structure and functioning of government is concerned, much of the likelihood of success revolves around the ability of political parties in government to rally around specific pieces of legislation in general and LGBT-oriented policies - a 
relatively niche policy area - in particular. This is measured in terms of party discipline, and this can be assessed on the relative uniformity of votes for prior legislation among members of the same party. Conversely, if parties are weak and heavily fragmented, it will be much more difficult to convince legislators to coalesce around bills for such niche causes as LGBT rights.

Party discipline - the relative cohesion of legislatures within their given political party - is relatively weak in Brazil. There is little in the way of party identification among votes and as such, the political party to which a legislator belongs is perhaps surprisingly non-predictive of how one will vote on most given issues. (Amex, 2002) While parties do tend to have identifiable and distinct ideological centers, they tend to be rather broad. The issues stem from a combination of using open-list proportional representation, high-magnitude electoral districts, lack of term limits, and state-level candidate selection. In addition, given the broadly haphazard nature of the Brazilian Congress, Presidents face a persistent and significant difficulty in pushing their measures through. However, party unity tends to increase substantially when rewards and punishments wielded by party leaders are sufficiently strong, and this varies on a case-bycase basis. Aside from the clout of party leaders, the cooperation of legislators with their parties is a function of (A) their stance among voters, and (B) the geographic concentration of their voting base. With this, we can hypothesize that niche interests such as LGBT rights are so difficult to pass through the legislature in that support tends to come from major coastal cities in which these criteria are fulfilled, and those represent a minority of Brazilian districts. 
State commitment in Brazil has been sustained for the most part, as evidenced by the outspokenness of former Brazilian president Luiz Lula da Silva. On June 5, 2008, he addressed the First National Conference of Gays, Lesbians, Bisexuals, Transvestites, and Transsexuals to unequivocally state his support for LGBT rights, conspicuously framing his support in a broader civil rights context. For instance, he exclaimed that, "[N]obody questions your sexual orientation when you pay your income tax, nobody questions it when you pay any tribute in this country. Why dsicriminate when you, freely, choose what you want to do with your body?" (pp. 268). In this sense, the speech seemed to make an assimilationist assumption. Later on, he stated that,

You know what I felt when I put this [LGBT rights-affirming] hat on my head, Tony? The same prejudice I felt against me when I put on the Homeless Movement hat. I had never been scolded so harshly. I was the newly elected president of the republic, and I put the Homeless Movement hat on my head. I was scolded in the press for I think a month. I could have put on the Bank of Brazil hat, the Real Bank hat, the Bradesco hat, the Vale do Rio Doce hat, the Petrobras hat, the Corinthians hat, the Flamengo hat, the Vasco hat, I could have chosen any of them... Now, I could not put on the Homeless [Movement] hat, and I saw a light: I will put them all on, because only like this can I break the prejudices that people have of thinking what you can and cannot do.

(Lula, pp. 268)

In this vein, Lula strongly suggests that LGBT rights are essentially another form of civil rights, comparing it to the rights of homeless people - another notable issue in Brazil given the children's rights movement which had developed in response to the military government shooting vagrant children to death. The final quote of this speech worth pointing to is, "It is a shame [that there were not more senators and deputies at the conference] because, upon seeing you, they would be surprised, and would make the exclamation: 'They are the same as me."' (p. 269). This concluding remark demonstrates 
a framing of LGBT issues as a much broader struggle for basic human rights. The speech more generally helps demonstrate the peculiar commitment of the Brazilian state to LGBT rights causes.

The Argentinian Congress has a notably cohesive and disciplined two-party structure, one of the reasons of which stems from the fact that elected officials by and large tend to follow very party-oriented paths to office, i.e. via a gubernatorial or presidential appointment, or a lower elected office (Jones, 2002). Much of the discipline stems from the rules governing elections and legislation, perhaps most notable among them being the committee system. Some committees, such as the budgetary or foreign affairs committees, allow for great steering and clout whereas others such as the culture or disability committees tend to offer less of this. The proverbial kingmakers in this process are party leaders, which mean there exists a very high cost of defection. Further, the Peronists of the Justicialist tradition faced deep persecution during the junta years of the 1970 s and early 1980s, thereby cultivating a deep sense of identity and subsequent loyalty among their ranks. With respect to the position of party leaders - the role of which is assumed by the President for whichever party he or she belongs to - can help explain the success of same-sex marriage legislation in Argentina, particularly as President Cristina Fernandez de Kirchner was an outspoken advocate by the time the bill came to a vote. This, combined with the Justicialists' majority in Congress, was in large part what pushed that bill through in the end.

Finally, as per Londregan (2002) with respect to Chile, the Senate is unique among legislative chambers both within and outside Latin America in that there is a panel 
of seats reserved for appointed legislators who were appointed by the outgoing Pinochet regime in the early 1990s. In a study examining the homogeneity of these eight or nine appointed seats vs. the remaining 38 seats which are elected, Londregan found virtually no correlation which suggested the existence of a bipolar (two-party system) model, nor which suggested homogeneity among preferences of appointed Senators. There is debatably a very loose pair of coalitions which forms a de facto two-party system, but if there is, "party" discipline is very limited - more akin to that seen in Brazil rather than in Argentina. Given these developments, it is difficult to say why the status of LGBT rights legislation is where it is (very limited to nonexistent), but we might preliminarily hypothesize that similar problems persist as those in the Brazilian legislature. Niche issues such as LGBT rights would have a difficult time passing through such a system, and the fact that the democratic transition took place later on in Chile may also serve as a hindrance.

In essence, we would do well to account for the institutional framework within which laws are crafted and delivered. A relatively niche issue such as protections specifically for LGBT individuals and/or families can only be expected to pass legislative chambers composed of strong coalitions that can foster agreement within their ranks. The judiciary needs to be accounted for as well in light of the fact that same-sex unions have been granted legal status through that branch of government in Brazil and Colombia. This proceeds to tie I with the constitutional language hypothesis, thought there is some circumstantial evidence that the Brazilian Supreme Federal Court ruled as it did courtesy of President Lula having appointed a majority of its judges by that point in time (de Santa 
Cruz, Jardim \& Garoupa, 2011). Beyond that, it is difficult in this context to analyze judicial behavior in a manner often executed in studies of American politics in light of scarce data.

\section{LGBT Rights Opposition}

$H_{5}$ : Closer ties between church and state, along with an influx of Evangelical Protestant lobbying tends to impede the progress of LGBT rights in a country.

Broadly speaking, the Catholic Church, standing in contradistinction from the Protestant churches of the nearby former British colonies of the Caribbean, tends to be viewed as a cultural institution rather than a rigid and concrete one. As such, Catholic leaders have by and large had less concrete impact on policy within Latin American countries relative to their Protestant counterparts in the British Caribbean (Wilets, 2010). Given the heavily Roman Catholic nature of the continent, it stands to reason that a majority of lawmakers and judges are at least nominally of the Catholic faith. Interestingly, although the Catholic Church has been the most outspoken, visible, and obvious opponent of such policy measures as same-sex marriage and anti-discrimination statutes, it has seen little success in actually stemming the tide of LGBT rights. While there were successful blocks or delays in Venezuela (Merentes, 2000), the Argentine judiciary (Schulenberg, 2012), and Chile (Núñez González, 2010), they ultimately failed in the countries that have seen the most substantial progress. As Goldfrank and Rowell (2012) point out, Church leaders in states with little regard for secularity have been the most reluctant to speak out against state abuses. Conversely, Church leaders in more 
historically secular Latin American states have tended to be the most vocal in their condemnation of human rights abuses by their governments. Argentina is perhaps the best example of the former, with Uruguay representative of the latter. In the context of states passing anti-LGBT laws, we might expect the Argentinian Catholic Church to be among the most vocal in attempting to derail pro-LGBT legislation or rulings prior to its passage, but then to stand on the proverbial sidelines once it has passed. Much the opposite should be expected in Uruguay. 


\section{CHAPTER V}

\section{VARIABLE SELECTION FOR HYPOTHESIS TESTING}

Given that the purpose of this study is to introduce a systematic empirical analysis of the process of LGBT rights development in South American, and specifically to explore why there exists a disparity between the countries of the region in this respect, we will need to carefully define the dependent variable - the enactment of LGBT rights policies - as carefully as possible. Following that, we can proceed to select which independent and control variables should prove most relevant in painting the picture we are looking for in the process.

\section{Establishing the Scope of Jurisdiction}

In an effort to effectively control for as many background factors as possible, we will need to narrow the scope of countries selected to a relatively homogeneous region in terms of religious traditions, socioeconomic status, and colonial history. Given these initial parameters, coupled with the focus on Latin America generally, the most prudent scope of analysis would likely be the ten countries on the South American continent. Mexico, Central America, and the Latin American Caribbean nations are fundamentally distinct from the South American nations demographically, as well as in terms of size and 
recent history. Further and perhaps more pertinent is that there are a number of integration efforts such as the MERCOSUR common market scheme in which the South American countries have attempted to form a multinational block akin to the European Union, meaning there is more economic and political integration on the continent apart from the remainder of Latin America. Finally, the practical issues of data availability, time, and status ambiguity dictate that not every country in the region may be realistically integrated into this study. ${ }^{6}$ As a result, the jurisdictional units of analysis fall to the ten Latin American countries in South America, which is to say every country except Guyana, Suriname, and French Guiana.

With this case selection, we can also ensure that level of economic development, public opinion with respect to most LGBT rights initiatives, and whether or status as a democracy are held constant. As Corrales (2014) pointed out, there is little reason to believe that economic development status has any substantial impact on LGBT rights in this context, even though it may have in past studies within the U.S. or Europe. However, it may not be assumed that results from a study of this nature will necessarily apply in the same capacity to non-democracies or to entirely different cultures. By and large, it speaks to the Latin American experience and may be generalizable to the remainder of Latin America as long as one is careful to account for the differences in recent history and public opinion on this and related matters. An attempt to generalize this to Eastern Europe - which has a roughly parallel recent history of emerging from decades of authoritarianism and very low trust in political institutions - the differences in religion,

\footnotetext{
${ }^{6}$ For example, Cuba is highly authoritarian and thus has very unreliable official data on even basic demographic characteristics; Puerto Rico is not an independent country but is part of the U.S., etc.
} 
political culture, and intra-regional dynamics will likely be confounding to the point of yielding unreliable analysis

\section{Dependent Variable ${ }^{7}$}

As noted earlier, there needs to be more than one specific policy under examination in order to determine the full nature of LGBT rights, meaning we must not, for example, examine only same-sex marriage or civil union legislation, as is common in other literature on the subject. Given that protection from non-state actors is no less crucial for comprehensive LGBT rights as is recognition of unions and other rights by the state, it is important to include such measures as anti-discrimination legislation as well. ${ }^{8}$ As such, this study will take into account factors going into the enactment of same-sex marriage, civil unions, anti-discrimination policies, joint adoption laws, and whether or not one can serve while openly LGBT in the military. ${ }^{9}$ In an effort to capture the full extent of the momentum that exists in each country, it will be vital to not account not only for those policies which have successfully been implemented, but those which have surfaced and advanced partially through the legislature or courts. Thus, if a bill was at least introduced in one chamber but blocked shortly thereafter, it will be accounted for as

\footnotetext{
${ }^{7}$ For further details on variable coding and sourcing, reference the appendix section.

${ }^{8}$ There may be some contention with the treatment of all four policies as identical, but for our purposes, it will likely yield the best results since same-sex marriage has so far been enacted in only three countries, and not until the final year of observation in two of them.

${ }^{9}$ Anti-discrimination policies include prohibitions on discrimination in employment, housing, and social and public services. Some variation between policies enacted depending on the country.
} 
an attempt at passage, as will a circuit-level court case that proceeds to an unsuccessful appeal.

\section{Independent Variables}

The criteria for gauging whether or not a national constitution features language establishing the parameters for marriage or other legal unions for the purpose of family formation is fairly straightforward, as is the criterion for deciding whether that language is specifically gendered. The text of each constitution will need to be examined so as to weed out any potential implications for marriage or family unions, which is present in at least some constitutions in the region (Moreira, 2012; de la Cruz, 2013). It should be noted that unlike most constitutions, those of Latin American countries tend to be unusually detailed and lengthy, often establishing positive rights such as access to minimal levels of health care and education. As such, there are unusual features within these constitutions, including at times the inclusion of regulations and rights surrounding the formation of families and/or legal unions.

Because the realization of minority rights in general seldom happen absent concerted effort on the part of interest groups relentlessly pushing for policies protecting them or otherwise establishing laws which allow for the fulfillment of their basic rights, it is paramount to determine the role that social movements have played in the enactment of LGBT rights policies in South America. Traditionally, data on the net wealth of organizations have been used (Haider-Markel \& Meier, 1996; Haider-Markel, 2001), but such has proven too impractical for this study. In lieu of measuring the overall wealth of 
the LGBT rights organizations within each country, we will track the number of reported movements in each country for each year studied, and examine whether consolidation has taken place. The act of consolidation can serve as a stand-in for the overall resource mobilization and professionalism of a country's social movement groups, even if it is an indirect or imperfect measure (Schulenberg, 2010; Piatti-Crocker, 2010; Schulenberg, 2012). The main rationale for this stems from the fact that groups that have formed from the splicing of previously splintered movements will likely have had more time to develop and will thus be more sophisticated on the whole.

On a related note, we will also capture HIV/AIDS-related efforts in each country by examining the number of groups present in each country as well as discerning whether or not the country in question has established an HIV/AIDS-targeting government agency. Because of its initial status a predominantly homosexual disease, coupled with the fact that LGBT rights groups have often asserted AIDS-related causes as top priorities, it can serve as a useful metric for the overall LGBT interest group activity taking place in a given country. On a more practical level, the data for such is widely and publicly available. This broad-based approach should provide the most in-depth analysis feasible, given available data.

Conventional wisdom holds that left-leaning parties should prove more amenable to LGBT rights and otherwise relatively liberal positions on social issues generally, while the converse should be true of right-leaning parties. Initial research on the matter in South American countries (Brown, 2002; Frasca, 2005; Merentes, 2008; Piatti-Crocker, 2010; Schulenberg, 2010) suggests that this is not necessarily the case. The socialist 
governments of Venezuela and Bolivia have seen minimal support or prioritization of LGBT issues, for example. Conversely, the right-leaning former president of Chile, Sebastián Piñera, openly supported same-sex marriage nationwide there in 2006 (Estrada, 2006). In light of this, it would be prudent to pinpoint those parties whose platforms or histories suggest social conservatism in particular. Parties that are broadly center-right but specify market liberalism, free trade, or globalization as the key drivers of their platforms will not necessarily qualify as right-leaning for the purposes of this study.

Further, because presidents tend to be so powerful and influential in Latin American countries, largely as a legacy of Cold War-era military juntas, it will be worth capturing the stance of the president on legislative matters. We have seen, for instance, that the president serves a very influential role in rallying support among partisans in Argentina (Schulenberg, 2012), though this influence varies by country. Luiz Inácio Lula da Silva of Brazil was among the most vocal supporters of same-sex unions to date, for example, but little progress has been seen there on the legislative front due at least in part to lax party discipline. On aggregate, however, there is reason to suspect that a positive trend in presidential support and legislative success will be present, given other favorable conditions.

Finally, because so many LGBT rights successes have emerged from the judiciary, it is important to capture the as many relevant court cases, at least on the federal level, as possible. As such, each court case will effectively count as an attempt to pass legislation, though it is to be counted separately given the dynamics unique to judicial decisionmaking. 
As noted prior, an overwhelming majority of opposition to LGBT rights comes from religious leaders and organizations. While every country under examination is overwhelmingly Catholic, there are some other variables that show change country-bycountry. One is the proportion of Protestants, which has grown rapidly throughout the region in recent years to the point that it has become a substantial majority with an ability to sway politics by forming electoral blocs. This has been most notable in Brazil but the Protestant and evangelical growth has been visible across the entirety of Latin America and much of the rest of the developing world ("Hola, Luther," 2008; "Brazil's Changing Religious Landscape,” 2013). Further, because federal-level anti-discrimination legislation has been blocked by a bloc of evangelical legislators, it stands to reason that a relationship can be expected to exist between the influence of these leaders and blockage of LGBT rights legislation.

More broadly speaking, religiosity - the level of influence that religion has in one's life - is often used as a related predictor in attempting to determine the palatability of LGBT rights issues (Haider-Markel \& Meier, 1996; Haider-Markel, 2001). This refers not to which specific religion respondents adhere, but how great a role religion plays in one's everyday life. The well-respected polling firm Gallup maintains a semi-annual global report on these numbers. We should expect for greater religiosity to correlate negatively with success in passage of LGBT rights policies. In addition, the religiosity measure may arguably serve as a stand-in for the influence of the Catholic Church in a given country, given the overwhelming Catholic tilt of the region in general. 


\section{CHAPTER VI}

\section{ANALYSIS}

\section{Descriptive Statistics}

As alluded to prior, there exists a wide disparity in LGBT protections across the South American region, though there has been substantial progress in most countries within the past decade or so. This study will count five distinct policies as signaling greater respect for LGBT rights on the part of the state: Same-sex marriage, same-sex civil unions, laws barring discrimination in the workplace, laws allowing same-sex couples to jointly adopt children, and allowing LGBT soldiers to serve openly in the military. Below is a chart of the ten countries under examination and the laws, if enacted, with the year during which they were enacted. 
Table 1

LGBT Rights-affirming Policies by Country and Year of Enactment

\begin{tabular}{|c|c|c|c|c|c|}
\hline Country & Marriage & $\begin{array}{l}\text { Civil } \\
\text { Unions }\end{array}$ & $\begin{array}{l}\text { A-D } \\
\text { Law }\end{array}$ & $\begin{array}{l}\text { Joint } \\
\text { Adoption }\end{array}$ & $\begin{array}{l}\text { Open } \\
\text { Service }\end{array}$ \\
\hline & 2010 & 2010 & - & 2010 & 2009 \\
\hline ARG & & & 2009 & - & \\
\hline BOL & 2013 & 2011 & - & 2010 & 1988* \\
\hline BRZ & - & - & 2012 & - & $1998 * *$ \\
\hline $\mathrm{CHI}$ & - & 2007 & 2011 & - & 1999 \\
\hline ECU & - & 2008 & 1997 & - & 1997 \\
\hline PAR & - & - & - & - & $\begin{array}{l}- \\
2009\end{array}$ \\
\hline PER & 2013 & 2009 & 2004 & 2009 & 2009 \\
\hline VEN & - & - & - & - & 1999 \\
\hline
\end{tabular}

*1988 constitution bars discrimination, which has been interpreted as including the barring of anti-LGBT discrimination for military service.

** Sodomy was decriminalized in 1998, and there was never an official ban on open military service.

As of 2014, at least some action has been taken in all but one of the countries under examination, with three having gone as far as enacting full same-sex marriage on a nationwide basis. In addition to the policy results noted in the descriptive statistics, numerous unsuccessful efforts have been made prior to the passage of successful LGBT rights-affirming policies. In many cases, as with same-sex unions in Venezuela or anti- 
discrimination laws in Brazil, there has yet to be any concrete policy success on a nationwide level.

Table 2

Descriptive Statistics for Independent Variables

\begin{tabular}{r|ll}
\multicolumn{2}{c}{ Mean } & Std. Dev. \\
\hline Language & .69 & .856 \\
Federal & .22 & .417 \\
HIV/AIDS Agency & .16 & .365 \\
HIV/AIDS Groups & .10 & .301 \\
Right-wing Share & 1.40 & .92 \\
Pres. Support & $32.38 \%$ & $18.35 \%$ \\
Protestant \% & .26 & .349 \\
Secularity & $10.65 \%$ & $4.29 \%$ \\
& 2.95 & 1.034
\end{tabular}

A cursory observation of the mean scores for each variable show us that the aggregate favorability within national constitutions in South America shows substantial favorability, with the mean score showing over two-thirds of the relevant constitutional text to be favorable versus unfavorable to judicial recognition of same-sex unions. Approximately one-third of the legislative composition over this time period consisted of identifiably right-wing parties. The proportion of Protestants across the region has grown to more than ten percent, thereby suggesting a rapidly building clout within regional politics.

Before proceeding, it is important to distinguish between the date of successful passage and the number of attempts seen in a country through either lawsuit or legislation. Some of the countries that have seen the most attempts to date have seen 
minimal progress, while others that saw a critical enactments earlier on, meaning there were fewer attempts needed for progress to take place. Figure 1 illustrates this phenomenon.

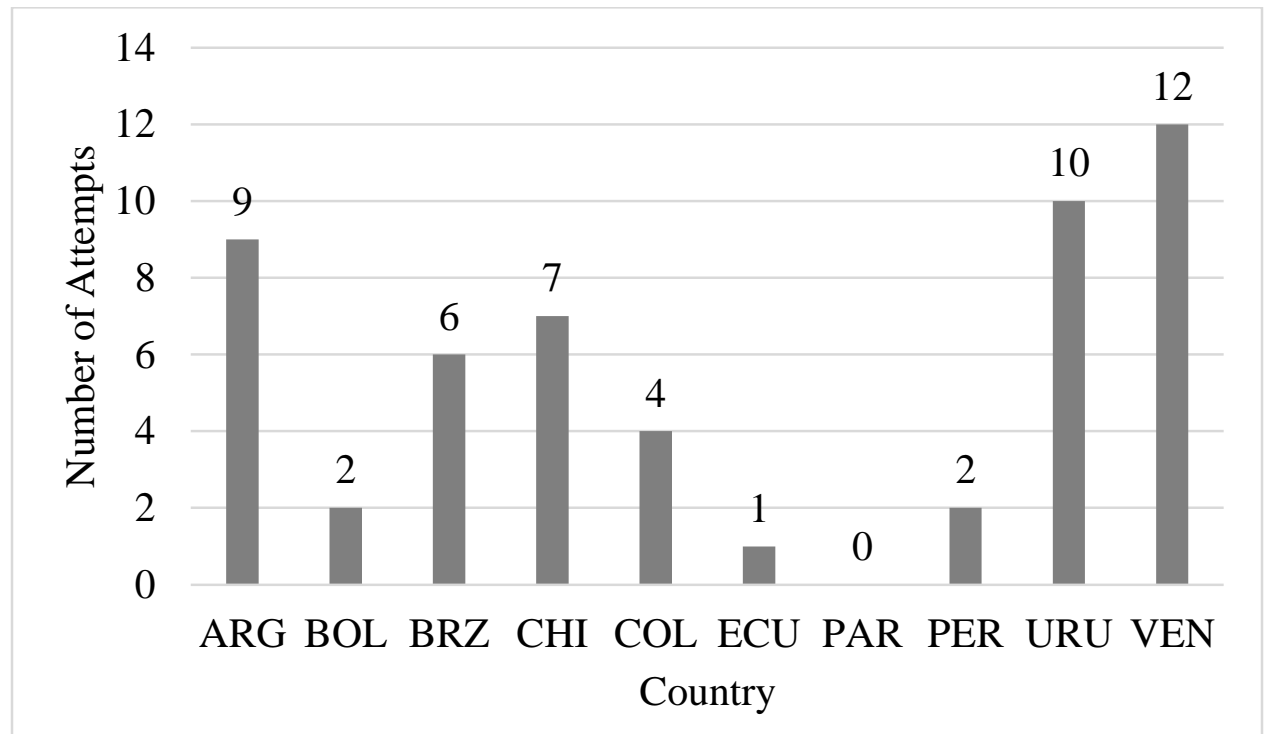

Figure 1. Cumulative Attempts at Passage of LGBT Rights Initiatives, 2000-2013.

This graph shows that, for instance, significant action has been taken in Venezuela, though this is at least in part because there has yet to be a significant LGBT rights policy passed on the federal level. Thus, a high number of attempts does not necessarily equate to progress and vice versa, given the early success of antidiscrimination law codified in the 1998 constitution. Nevertheless, countries such as Uruguay and Argentina have seen enactment of full same-sex marriage, whereas Paraguay has seen no progress of the sort concerned here to date. 


\section{Methodology}

This analysis will take the form of an event-history analysis, specifically via a Cox regression. EHA proves particularly useful for diffusion research in that it incorporates a time variable, thereby allowing one to account for intra-observation variation over the course of a study's time frame. In essence, an EHA follows a series of observations which are arranged in timed blocks, following that observation block up to the point at which the event occurs. For each time unit within the observation block that lies before the event, the unit is coded with a 0 . When the event occurs, it is coded with a 1, after which point the observation block "dies," or falls out of the dataset. Another term applied to EHA is proportional hazards model or survival analysis in light of the fact that it measures rate at which the unit of analysis survives within the dataset before covariates lead it to drop out.

In comparison with binary and probit models, for instance, there is an inherent advantage in that it takes the history and context surrounding a phenomenon into account as opposed to merely reporting whether the event occurred or not. In addition, there is an advantage over the use of ordinary least-squares regression (OLS) models in that it avoids data truncation by accounting for the time at which the observations begin taking shape and, if ongoing indefinitely, accounts for observations happening afterwards. When data observations occur outside of this time frame in an OLS model, one must make arbitrary assumptions that events begin and end at times when they have not, and this can in turn lead to bias. EHA corrects for such likely bias by censoring data points from the 
set of observations rather than effectively pretending as though they never happened or have prematurely ended (Box-Steffensmeier \& Woo, 2011).

In the case of this analysis, the dependent variable will consist of actions taken which ultimately lead up to a critical action that has been taken by the state in question. Once the critical action occurs, all subsequent observations for that particular country will drop from the data set, as it has "died" in the sense that the chief occurrence enactment of a major LGBT rights initiative on the federal level - has occurred and thus no further observations are warranted. The factors of interest are: The coefficient (B), a positive number showing increased risk of adoption and a decreased period of time prior to critical action; the standard error (SE), and the hazard ratio $(\operatorname{Exp}(B))$, which denotes the ratio of hazards between two countries when all other variables are held constant. For example, if a the right-wing party share variable has a coefficient of .15 , then the hazard rate or risk of adoption increases by $15 \%$ with each unit increase in right-wing representation in that given country's legislature. The log likelihood and chi-square are the two remaining numbers of interest in a cox regression. The former tests for whether or not the addition of a variable adds to the likelihood that the event will occur, with a lower number tending to correlate with the addition of more variables due to the use in a proportional hazards model of a negative log likelihood. The chi-square tests the hypothesis that all coefficients used in the model are identical and equal to zero, with higher numbers suggesting a better overall fit given the relative lack of deviance between coefficients (Box-Steffensmeier \& Woo, 2011). 


\section{Application of the Methodology}

The data for this analysis consists of 140 state-years - 10 states over the course of 14 years, spanning from 2000 to $2013 .^{10}$ The commencement of the time scale was difficult to solidify, but because that decade is when a vast majority of actions have taken place, it is ultimately prudent and non-arbitrary. The states under analysis were chosen, as noted previously, because they are relatively homogeneous when it comes to several key factors ranging from colonial history to linguistics to political culture, thereby allowing us to effectively control for them. ${ }^{11}$ Because most states under examination have taken at least some action in the realm of LGBT rights as of 2013, there should be little concern that excessive censoring of cases will occur.

For purposes of clarification, the intention is to analyze the following: The events (attempts at passage of a law or a court ruling) are counted if and until the critical action (passage, enactment, or ruling) takes place, while those units of observation (countries) that have seen attempts without success remain "at risk" and should be considered likely candidates for such passage in the future. However, even if there has been no action taken in a given country, then there is still a chance that it can happen, even though it is less likely. The results of the Cox regression are shown in Table 3.

This analysis runs a total of five models. Model 1 focuses on attempts to win rights (particularly same-sex union recognition) through the judiciary, observing the

\footnotetext{
${ }^{10}$ Because of the nature of an event-history analysis, a number of observations, particularly later in the time scale, are dropped once the critical action for that country takes place. Thus, the total number of observations amounts to 110 .

${ }^{11}$ Venezuela has been included as a control variable, given its unique political and particularly legislative composition during this time frame.
} 
impact of social movements and secularity of the government. Model 2 focuses on the impact of extra-governmental groups from both sides of the issue, including the social movement variables as well as the trend in Protestantism within the given countries. Model 3 attempts to discern the impact of religious groups, postulating a negative correlation in this case. Model 4 intends to focus on the impacts of the legislature, with another postulated negative correlation given higher degrees of right-wing composition. Finally, Model 5 includes all variables for a thorough multivariate analysis.

\section{Results}

Table 3

Factors Influencing State Action on LGBT Rights

Variable

Model 1

B

(Std.

Err.)

$\operatorname{Exp} .(B)$

\begin{tabular}{|c|c|c|c|c|c|}
\hline Language & $\begin{array}{l}.520 * \\
(.214) \\
1.681\end{array}$ & - & $\begin{array}{l}.838 * * * \\
(.198) \\
2.312\end{array}$ & - & $\begin{array}{l}1.133 * * * \\
(1.405) \\
3.924\end{array}$ \\
\hline Federal & - & - & - & $\begin{array}{l}-.568 \\
(1.071) \\
.567\end{array}$ & $\begin{array}{l}1.367 \\
(1.405) \\
3.924\end{array}$ \\
\hline Consolidation & $\begin{array}{l}1.977 * * \\
(.682) \\
7.219\end{array}$ & $\begin{array}{l}-.060 \\
(.591) \\
.941\end{array}$ & - & $\begin{array}{l}.558 \\
(1.132) \\
1.747\end{array}$ & $\begin{array}{l}.759 \\
(1.138) \\
2.136\end{array}$ \\
\hline $\begin{array}{r}\text { HIV/AIDS } \\
\text { Agency }\end{array}$ & $\begin{array}{l}-1.928 * \\
(.816) \\
.145\end{array}$ & $\begin{array}{l}.663 \\
(.598) \\
1.941\end{array}$ & - & $\begin{array}{l}.701 \\
(.598) \\
2.015\end{array}$ & $\begin{array}{l}-.414 \\
(1.074) \\
.661\end{array}$ \\
\hline
\end{tabular}

Model 5

Model 4

\section{(1)}




\begin{tabular}{|c|c|c|c|c|c|}
\hline $\begin{array}{r}\text { HIV/AIDS } \\
\text { Groups }\end{array}$ & $\begin{array}{l}1.158^{* * * *} \\
(.314) \\
3.184\end{array}$ & $\begin{array}{l}-.042 \\
(.146) \\
.959\end{array}$ & - & $\begin{array}{l}-.017 \\
(.145) \\
.983\end{array}$ & $\begin{array}{l}1.560 * * * \\
(.365) \\
4.760\end{array}$ \\
\hline $\begin{array}{r}\text { Right-wing } \\
\text { Share }\end{array}$ & - & $\begin{array}{l}-.019 * \\
(.009) \\
.981\end{array}$ & $\begin{array}{l}-.017 \\
(.009) \\
.983\end{array}$ & $\begin{array}{l}-.018 \\
(.010) \\
.982\end{array}$ & $\begin{array}{l}.016 \\
(.013) \\
1.016\end{array}$ \\
\hline Pres. Support & - & - & - & $\begin{array}{l}-.276 \\
(.339) \\
.759\end{array}$ & $\begin{array}{l}-.723 \\
(.423) \\
.485\end{array}$ \\
\hline Protestant $\%$ & - & $\begin{array}{l}-.141 * * * \\
(.027) \\
.869\end{array}$ & $\begin{array}{l}-.166^{* * *} \\
(.040) \\
.847\end{array}$ & - & $\begin{array}{l}-.262 * * * \\
(.050) \\
.769\end{array}$ \\
\hline Secularity & $\begin{array}{l}1.291 * * * \\
(.353) \\
3.637\end{array}$ & - & $\begin{array}{l}-.035 \\
(.204) \\
.965\end{array}$ & - & $\begin{array}{l}1.517 * * \\
(.452) \\
4.561\end{array}$ \\
\hline Venezuela & - & $\begin{array}{l}-.392 \\
(.460) \\
.676\end{array}$ & $\begin{array}{l}-.023 \\
(.464) \\
.977\end{array}$ & $\begin{array}{l}.112 \\
(1.053) \\
.011\end{array}$ & $\begin{array}{l}-.356 \\
(1.242) \\
.701\end{array}$ \\
\hline $\begin{array}{r}-2 \log \\
\text { Likelihood }\end{array}$ & 539.490 & 554.344 & 528.504 & 552.993 & 495.474 \\
\hline$X^{2}$ & 24.329 & 12.074 & 37.739 & 13.341 & 75.075 \\
\hline
\end{tabular}




\section{CHAPTER VII}

\section{DISCUSSION}

The constitutional language $\left(H_{1}\right)$ hypothesis is strongly supported, while the social movements $\left(H_{3}\right)$ institutional $\left(H_{4}\right)$, and $\left(H_{5}\right)$ hypotheses are supported with caveats; and the federalism $\left(\mathrm{H}_{2}\right)$ hypothesis has little empirical support. The federalism hypothesis likely failed to show much in the way of significance in light of the fact that there were delays in such federal republics as Brazil and Argentina relative to other countries under examination in adopting a substantial LGBT rights policy. This in turn may have stemmed from the observed effects of religious groups, both Protestant and Catholic. Further, because of the unusual political situation in Venezuela given the distinctly socialist government seen under the late president Hugo Chavez, there was ultimately reason to control for it in the analysis. Because Venezuela is the remaining federal republic, the results for this variable were likely skewed further in the direction opposite what was predicted. As far as the support of the president is concerned, there was no apparent relationship for similar reasons that the federalism hypothesis proved less than explanatory.

The social movement variables showed cursory significance, and it may have been stronger had the data gathered for its inclusion been less crude. Notably, the first 
model, which focuses on the judicial process of achieving same-sex unions, there is considerable significance, thereby suggesting that there has so far been the more productive route to take. The constitutional language variable, it is worth noting, showed significance in this realm as well, as should be expected. Because the first substantial action taken in three of the seven countries which ultimately did was done through the judiciary, constitutional application would likely prove very relevant. The variable measuring Protestantism showing significance is hardly a surprise, since the largest growth in evangelical Protestantism has occurred mainly in Brazil and Chile, and the first substantial pro-LGBT policy enactments there were at least somewhat delayed relative to other countries. The church-state relationship variable appears explanatory in two of the three models in which it was employed, thereby suggesting that it plays some role in quickening the pace of adoption. This was observed in the case study for Argentina wherein the high court reversed the ruling of a lower court in Buenos Aires arguing for same-sex unions, citing specifically Catholic precedent. The share of a legislature that is identifiably right-wing appears to impede progress when social movement actions are taken into account, as per the second model, but not in any other case. This is to be expected, since the legislature has much more discretion in how to respond to these groups than do the courts. 
CHAPTER VIII

\section{LIMITATIONS}

One of the most notable limitations of this research is that there is little ability to distinguish between the actions of courts versus those taken by legislatures. While the inclusion of constitutional language and political party variables allows for some analysis of their effects, it still remains unclear as per the data utilized in this study as to which branch of government was responsible for the first substantial policy step. Another point of contention likely stems from the lack of available data on the wealth and resource distribution (Haider-Markel \& Meier, 1996) of LGBT organizations in each country, it proved difficult to gauge their impact. An alternative method of measuring the proliferation of LGBT rights organizations in a country would be to simply record the number of active groups, but this is exceedingly difficult when attempting to measure the effects of each variable over a period of time. It was for this reason that the number of HIV/AIDS groups and government agencies was used as a stand-in, though imperfect such a substitution is likely to be. Finally, because it was held as a constant in this case, the role of the Catholic Church itself cannot be discerned. However, as seen in the case of Argentina when appeals were struck down by the high court on explicitly Catholic grounds and in Venezuela when a constitutional amendment barring discrimination was 
blocked, it has a unique influence that could stand to be distilled further.

Ultimately, a more robust analysis would be possible if (A) the differential impacts of legislative vs. judicial decisionmaking, and (B) social movements are incorporated more thoroughly into the data such as the nuances described in the literature review may be explored rather than simply gauging whether a substantial consolidation had occurred. This would have been much more feasible had time not been factored into the analysis, e.g. via execution of an ordinary least-squares (OLS) regression, but this would have lent itself to a host of different limitations. The time variable is key when measuring the influence of factors that show lagged effects, as was the case here. 


\section{CHAPTER IX}

\section{DIRECTIONS FOR FUTURE RESEARCH}

With this study being the first rigorous, systematic, and quantitative examination of LGBT rights in South America, it should serve as a valuable contribution to the small albeit rapidly growing body of literature on the subject. There are nevertheless some serious limitations which pave the way for more comprehensive research on the matter in the future. Given the limitation inherent in a crude dummy coding for a phenomenon with as much nuance and fine-grained detail as social movements, future researchers would undoubtedly do well to investigate these nuances and political dynamics within each country so as to better determine the factors which drive both the discourse and policy processes with respect to LGBT rights in South America. Much the same should be said of research on pro-LGBT social movements within the region. Moving beyond a single region, more ambitious future researchers may apply the lessons of South America to other developing regions in Africa or Asia. Granted, the unique political cultures, histories, and other factors will provide challenges for this approach, but given the dire state of LGBT rights in most of these regions, there is reason to pursue such research. One other major aspect of LGBT rights in South America revolves around the influence of the global community and its burgeoning influence in this realm (Friedman, 2012; de 
la Cruz, 2013). As such, a more rigorous examination of its effects may be examined as such events unfold, as they are evidently significant albeit very difficult to examine systematically.

It must be emphasized that, aside from the quantitative results from this, there is at least some qualitative evidence within the literature examined to suggest a more robust relationship. From a practical standpoint, if the successes seen in the countries examined here are to be replicated in other countries or even in entirely different regions of the world, then it stands to reason that the most readily available resources to marginalized groups will come in the form of extra-governmental organization. While it is technically possible to alter constitutions or to elect relatively socially radical parties to government, it is a monumental task in the absence of sufficiently organized and cohesive social movements to spearhead such drives. As seen in the results of this analysis, success is most likely when pursued through the courts when there is enough of an opportunity available through either judicial innovation by way of influence from countries like the U.S., or when the constitution contains language amenable to a positive ruling. Nevertheless, the legislature matters as well, meaning socially conservative parties can impeded progress. As de la Cruz (2013) suggests, any organized groups in Latin America, at the very least, would do well to "follow the leader" embodied in the example of Spain. Groups would maximize success by establishing concrete demands for full marriage equality and refusing to back down for any compromise or substitute unless it becomes impossible to achieve, find a maximally friendly political party and push the agenda through via their leadership, and maneuver around the opposition by establishing 
local-level implementations so as to demonstrate the real impacts of such laws so as to assuage the need for idle speculation. 


\section{REFERENCES}

Ames, B. (2002). Party Discipline in the Camber of Deputies. In S. Morgenstern, \& B. Nacif, Legislative Politics in Latin America (pp. 185-221). New York: Cambridge University Press.

Avery, D. (2012, April 9). Queerty. Retrieved from Brazil Is A Gay Traveler's Paradise, But Violence Against LGBTs Is On The Rise: http://www.thedailybeast.com/articles/2012/04/08/brazil-s-surge-in-violenceagainst-gays-is-just-getting-worse.html

Beck, G. (2012, July 26). Who's the bigot: Christians? Or those attacking them? Retrieved from Glenn Beck: The Fusion of Entertainment and Enlightenment: http://www.glennbeck.com/2012/07/26/who\%E2\%80\%99s-the-bigot-christiansor-those-attacking-them/

Berry, F. S. (1994). Sizing Up State Policy Innovation Research. Policy Studies Journal, 442-456.

Bonomo, C. A. (2013). Case Studies in the Advancement of Sexual Orientation Rights and the Role of Developing International Legal Norms: Argentina and Brazil . Chicago Journal of International Law, 259-89.

Box-Steffensmeier, J. M., \& Woo, B. (2011, October 4). Event History Analysis. Retrieved August 7, 2013, from International Encyclopedia of Political Science: http://knowledge.sagepub.com/view/intlpoliticalscience/n202.xml?rskey=6v7FfC \&row $=3$

Brazilian Resolution. (2003). Retrieved from ILGA: http://ilga.org/ilga/en/article/406

Brazil's Changing Religious Landscape. (2013, July 18). Retrieved from Pew Research: Religion and Public Life Project : http://www.pewforum.org/2013/07/18/brazilschanging-religious-landscape/

Brown, S. (2002). "Con Discriminación y Represión, No Hay Democracia": The Lesbian and Gay Movement in Argentina. In J. Corrales, \& M. Pecheny, The Politics of Sexuality in Latin America: A Reader on Lesbian, Gay, Bisexual, and Transgender Rights (pp. 86-101). Pittsburgh : University of Pittsburgh Press. 
Brysk, A. (1993). From Above and Below: Social Movements, the International System, and Human Rights in Argentina. Comparative Political Studies , 259-85.

Cleary, E. L. (1997). The Struggle for Human Rights in Latin America. London: Praeger.

Código Civil de Argentina. (2014).

Código Civil do Brasil. (2014).

Constitución de la Nación de Argentina. (1994).

Constitución Política de Colombia. (n.d.).

Constituição da República Federativa do Brasil. (1988).

Constituição do Estado Mato Grosso. (1989).

Constituição do Estado Sergipe. (1989).

Corrales, J. (2010). The LGBT Organizational Density of World Cities. In J. C. Pecheny, The Politics of Sexuality in Latin America: A Reader on Lesbian, Gay, Bisexual, and Transgender Rights (pp. 372-80). Pittsburgh : University of Pittsburgh Press.

Corrales, J. (2014, January 29). The Usual Forces - with Surprising Results . Retrieved from Room for Debate (The New York Times) :

http://www.nytimes.com/roomfordebate/2014/01/29/why-is-latin-america-soprogressive-on-gay-rights/javier-corrales-noon-tues

de la Cruz, D. (2013). Explaining the Progression of the Rights of Same-Sex Couples in Latin America. San Diego International Law Journal, 323-57.

de Santa Cruz, O., Jardim, M. A., \& Garoupa, N. (2011). Choosing Judges in Brazil: Reassessing Legal Transplants from the United States. Amareican Journal of Comparative Politics, 529-62.

Díez, J. (2013). Explaining Policy Outcomes: The Adoption of Same-Sex Unions in Mexico City and Buenos Aires. Comparative Political Studies, 212-35.

Dworkin, S., \& Yi, H. (2003). LGBT Identity, Violence, and Social Justice: The Psychological Is Political. International Journal for the Advancement of Counseling, 269-79.

Encarnación, O. G. (2011). Latin America's Gay Rights Revolution. Journal of Democracy, 104-18.

Encarnación, O. G. (2014, January 29). Why Latin American Courts Favor Gay Rights. Retrieved from Room for Debate (The New York Times) : http://www.nytimes.com/roomfordebate/2014/01/29/why-is-latin-america-soprogressive-on-gay-rights/why-latin-american-courts-favor-gay-rights 
Escobedo, T. (2014, June 19). U.S. reduces money to Uganda over harsh anti-gay laws. Retrieved from CNN World: http://www.cnn.com/2014/06/19/world/africa/uganda-homosexuality-u-s-funds/

Estrada, D. (2006, May 17). CHILE: Law on Civil Union for Gays Within Reach . Retrieved from Inter Press Service News Agency : http://www.ipsnews.net/2006/05/chile-law-on-civil-union-for-gays-within-reach/

Jones, M. P. (2002). Explaining the High Level of Party Discipline in the Argentine Congress. In S. Morgenstern, \& B. Nacif, Legislative Politics in Latin America (pp. 147-84). New York: Cambridge University Press.

Keck, M., \& Sikkink, K. (1998). Activists Beyond Borders: Activist Networks in International Politics. Ithaca, NY : Cornell University Press.

Koo, J.-W., \& Ramirez, F. O. (2009). National Incorporation of Global Human Rights: Worldwide Expansion of National Human Rights Institutions 1966-2004. Social Forces, 1321-53.

LaBarbera, P. (2013, November 11). 'Gay' Power vs. Religious Liberty. Retrieved from http://www.wnd.com/2013/11/gay-power-vs-religious-liberty/:

Londregan, J. (2002). Appointment, Reelection, and Autonomy in the Senate of Chile. In S. Morgenstern, \& B. Nacif, Legislative Politics in Latin America (pp. 341-76). New York: Cambridge University Press.

Lula, L. (2008). Address to the First Global Conference on LGBT Rights. In J. Corrales, \& M. Pecheny, The Poltics of Sexuality in Latin America: A Reader on Lesbian, Gay, Bisexual, and Transgender Rights (pp. 265-71). Pittsburgh: University of Pittsburgh Press.

Lutz, E. L., \& Sikkink, K. (633-59). International Human Rights Law and Practicein Argentina. International Organization, 2000.

Makse, T., \& Volden, C. (2011). The Role of Policy Attributes in the Diffusion of Innovations. The Journal of Politics, 108-124.

Merentes, J. R. (2010). Gay Rights in Venezuela Under Hugo Chavez, 1999-2008. In J. Corrales, \& M. Pecheny, The Politics of Sexuality in Latin America: A Reader of Lesbian, Gay, Bisexual, and Transgender Rights (pp. 220-3). Pittsburgh: University of Pittsburgh Press.

Miceli, M. S. (2005). Morality Politics vs. Identity Politics: Framing Processes and Competition Among Christian Right and Gay Social Movement Organizations. Sociological Forum, 589-612. 
Moreira, A. J. (2012). We Are Family! Legal Recognition of Same-Sex Unions in Brazil. American Journal of Comparative Law, 1003-42.

Morgenstern, S., \& Nacif, B. (2002). Legislative Politics in Latin America. Cambridge University Press: Cambridge.

Murdie, A. M., \& Davis, D. R. (2012). Shaming and Blaming: Using Events Data to Assess the Impact of Human Rights INGOs. International Studies Quarterly, 116.

Notary RS accept gay marriage registration. (2004, March 4). Retrieved December 5, 2013, from Terra: http://noticias.terra.com.br/brasil/interna/0,,OI275352EI306,00.html

Piatti-Crocker, A. (2010). Construction of Policy Innovation in Argentina: From Gender Quotas to Same-Sex Marriage. In J. Pierceson, A. Piatti-Crocker, \& S. Schulenburg, Same-Sex Marriage in the Americas: Policy Innovation for SameSex Relationships (pp. 37-72). Lanham, Maryland: Lexington Books.

Religion in Latin America: Hola Luther. (2008, November 6). Retrieved from The Economist: http://www.economist.com/node/12564066

Reus-Smit, C. (2011). Struggles for Individual Rights and the Expansion of the International System . International Organization, 207-42.

Risse, T., \& Sikkink, K. (1999). The Socialization of International Human Rights Norms into Democratic Practices: Introduction. In T. Risse, S. Ropp, \& K. Sikkink, The Power of Human Rigths: International Norms and Domestic Change. Cambridge : Cambridge University Press.

Riverstone-Newell, L. (2012). The Diffusion of Local Bill of Rights Resolutions to the States. State and Local Government Review, 1-11.

Schulenberg, S. (2010). Policy Stability Without Policy: The Battle for Same-Sex Partnership Recognition in Brazil. In J. Pierceson, A. Piatti-Crocker, \& S. Schulenberg, Same-Sex Marriage in the Americas: Policy Innovation for SameSex Relationships (pp. 93-128). Lanham, Maryland: Lexington Books.

Schulenberg, S. (2012). The Construction and Enactment of Same-Sex Marriage in Argentina. Journal of Human Rights, 106-25.

Shipan, C., \& Volden, C. (2012). Policy Diffusion: Seven Lessons for Scholars and Practitioners . Public Administration Review, 1-9.

Sikkink, K. (2008). From Pariah State to Global Protagonist: Argentina and the Struggle for International Human Rights. Latin American Politics and Society, 1-29. 
Sullivan, A. (1995). Virtually Normal: An Argument About Homosexuality. New York: Random House.

Violence Against LGBTs. (n.d.). Retrieved from Galloway Family Foundation: http://www.gallowayfoundation.org/category-violence-against-lgbts/

Walker, J. L. (1969). The Diffusion of Innovations Among the American States. The American Political Science Review, 880-99.

Warner, M. (1999). The Trouble with Normal: Sex, Politics, and the Ethics of Queer Life. Cambridge, MA: Harvard University Press.

Wilets, J. (2010). Divergence Between LGBTI Legal, Political, and Social Progress in the Caribbean and Latin America. In J. Corrales, \& M. Pecheny, The Politics of Sexuality in Latin America: A Reader on Lesbian, Gay, Bisexual, and Transgender Rights (pp. 349-57). Pittsburgh: University of Pittsburgh Press.

Xie, S., \& Corrales, J. (2010). LGBT Rights in Ecaudor's 2008 Constitution: Victories and Setbacks. In J. Corrales, \& M. Pecheny, The Politics of Sexuality in Latin America: A Reader on Lesbian, Gay, Bisexual, and Transgender Rights (pp. 2249). Pittsburgh: University of Pittsburgh Press.

Yogyakarta Principles: Principles on the Application of International Human Rigths Law in Relation to Sexual Orientation and Gender Identity. (2007). www.yogyakartaprinciples.org.

Yoshino, K. (2006). Covering: The Hidden Assault on Our Civil Rights. New York: Random House. 


\section{APPENDIX}

\section{VARIABLE MEASUREMENT AND DATA SOURCES}

\begin{tabular}{|c|c|c|}
\hline Variable & Measurement & Source \\
\hline Critical Action & $\begin{array}{l}\text { A cumulative categorical } \\
\text { variable that will account } \\
\text { for each attempt up to the } \\
\text { point of adoption of one of } \\
\text { four key policies, } \\
\text { whichever is adopted fist. } \\
\text { Attempts will be dummy } \\
\text { coded } 0 \text { for lack of an } \\
\text { attempt or passage, and } 1 \\
\text { for an attempt or passage } \\
\text { with all subsequent } \\
\text { observations for that } \\
\text { country falling from the } \\
\text { data set. }\end{array}$ & $\begin{array}{l}\text { Various sources listed } \\
\text { in the References } \\
\text { section. Mostly culled } \\
\text { from Wikipedia- } \\
\text { directed sources which } \\
\text { show proper } \\
\text { documentation. }\end{array}$ \\
\hline Language & $\begin{array}{l}\text { A categorical variable } \\
\text { measuring conduciveness } \\
\text { to pro-LGBT interpretation. } \\
0 \text { represents least } \\
\text { conducive (recognition of } \\
\text { families mentioned, } \\
\text { gendered language), } 1 \text { (No } \\
\text { recognition of families } \\
\text { mentioned), and } 2 \\
\text { (Recognition of families, } \\
\text { non-gendered language). }\end{array}$ & $\begin{array}{l}\text { The constitution of } \\
\text { each country } \\
\text { examined, found } \\
\text { through } \\
\text { <http://www.wipo.int/ } \\
\text { wipolex/en/> }\end{array}$ \\
\hline Federal & $\begin{array}{l}\text { Dummy coded } 0 \text { for unitary } \\
\text { states and } 1 \text { for federal. }\end{array}$ & $\begin{array}{l}\text { CIA World Factbook: } \\
\text { <https://www.cia.gov/l } \\
\text { ibrary/publications/the } \\
\text {-world-factbook/> }\end{array}$ \\
\hline Consolidation & $\begin{array}{l}\text { Dummy coded } 0 \text { for those } \\
\text { countries having seen no } \\
\text { consolidation of their social }\end{array}$ & $\begin{array}{l}\text { Brown, 2002; Piatti- } \\
\text { Crocker, 2010; } \\
\text { Shulenberg, 2010; }\end{array}$ \\
\hline
\end{tabular}




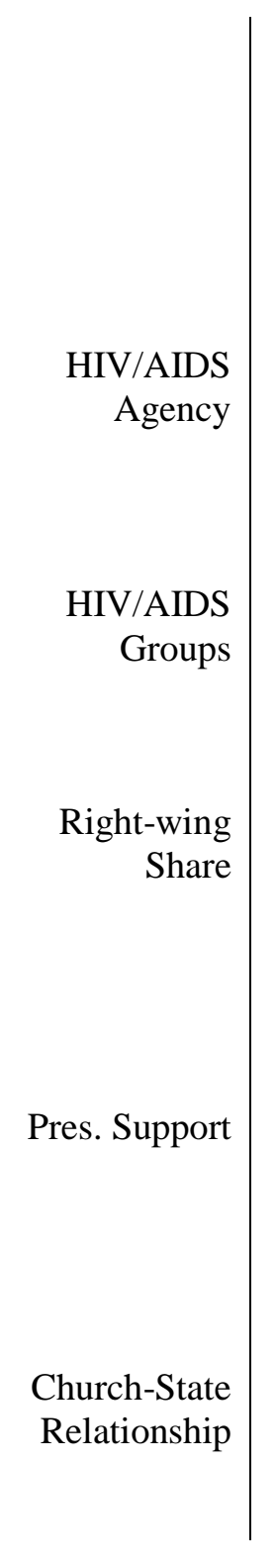

movements and 1 for those that have.

Dummy coded 0 for lack of a government agency dedicated to dissemination resources, 1 for countries that do have such an agency.

Number of HIV/AIDS organizations active in a given country.

Proportion of a legislature composed of distinctly right-wing political parties, particularly in the social realm.

Dummy coded 0 for lack of apparent support from a sitting president for at least one major LGBT rights initiative, and 1 for when such support is evident.

Categorical variable coded 0 to 2 , with zero showing tightest relationship between church and state and 2 showing the most secularity.
Shulenberg, 2012;

Bonomo, 2013; de la Cruz, 2013. LGBT organizations listed in Griego, 2008.

Griego, 2008.

Organizations listed in Griego, 2008.

Various entries on national legislative elections, culled from $<$ http://www.politicaen elmundo.com/>

Lula, 2008;

Schulenberg, 2012.

Constitutions of respective countries analyzed. 